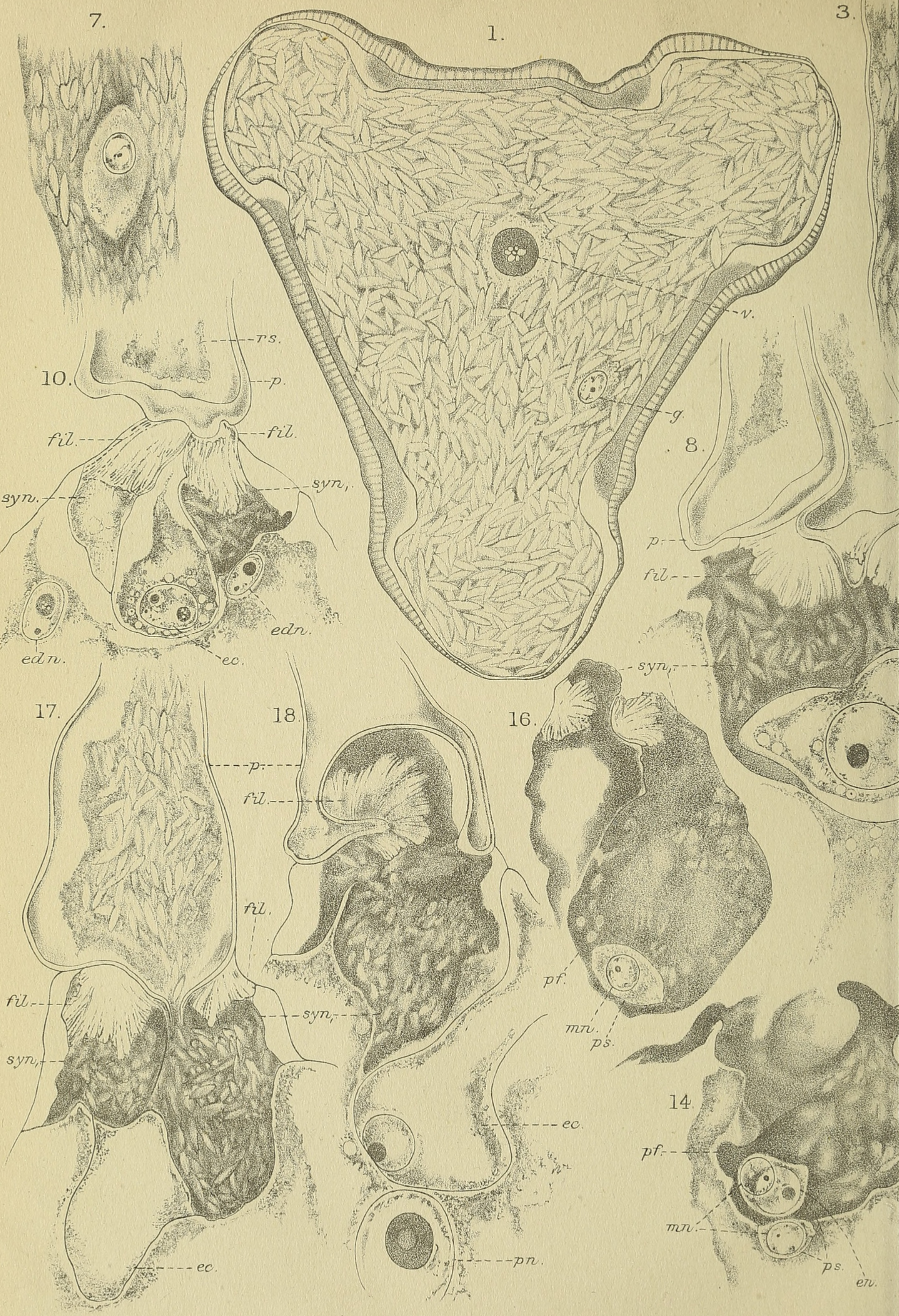




\title{
Studies on the Embryo Sac and Fertilization in Oenothera.
}

\author{
BY \\ M. ISHIKAWA, RIGAKUSHI, \\ Botanical Institute, Tokyo Imperial University, Fapan.
}

\section{With Plate VII and fourteen Figures in the Text.}

$\mathrm{T}$ HE present paper deals with the behaviour of the gametophytes and fertilization phenomena in Oenothera nutans and Oe. pycnocarpa as well as their hybrids; these two species were formerly included in Oenothera biennis until Atkinson and Bartlett (2) separated them as distinct species. The materials were collected during the summers of I9I I and I9I 2 in the Botanic Garden of the Cornell University, Ithaca, New York, U.S.A., where this work was commenced, and after the writer's return to Japan the work was carried out in the Botanical Institute of the Tokyo University, and completed in 1915 .

The embryo sac and fertilization phenomena of Oenothera were already studied by Hofmeister so long ago as I 847 (26), but he could not so fully make out detailed structures of the embryo sac as we do now. He published, however, a figure of tetranucleate embryo sac of Godetia rubicunda, a closely related species, and later in 1849 he gave a full description thereof (27). The investigations, to which the modern cytological methods were applied, are of comparatively recent date. In I 908 Geerts (20) published a brief account of the development of the embryo sac and fertilization in Oenothera Lamarckiana, which was followed by a detailed paper which appeared in the next year (21). On the other hand, Modilewski (42) independently studied the same subject, and concisely described various cytological features observed not only in Oe. biennis, but also in some other plants belonging to the Onagraceae. The results obtained by these two investigators agreed in the essential points that the embryo sac is tetranucleate, and that one pole nucleus and the whole antipodal apparatus are absent. Renner (55) was the third who made a careful study of the embryo sac, fertilization, and subsequent nuclear divisions in Oenothera biennis, Oe. Lamarckiana, Oe. muricata, as well as their hybrids, and made some additional contributions, besides affirming the absence of the melogony

[Annals of Botany, Vol. XXXII No. CXXVI. April, 1918.] 
which was reported by Goldschmidt (23) as having occurred in those plants. Lately Werner (73) published a paper on the embryo sacs of Oe. biennis, Oe. Lamarckiana, and some others, and she discusses in the same paper some ecological relations existing between the gametophyte and ovular tissues. Besides, there are a considerable number of papers dealing with the reduction phenomena in Oenothera, which lie beyond the scope of the present paper.

Although the nuclear phenomena of the gametophyte and fertilization of Oenothera seem to have been fully described in the papers referred to above, there still remain not a few points which require a careful investigation. The present work was therefore undertaken in order to get an accurate idea about the fertilization, especially with special reference to the behaviour of the synergids at the time of the attack of the pollen-tube. In the course of the present investigation, the materials selected were found very suitable for the purposes.

Several fixing reagents were tried, but Bouin's solution as recommended by Gates (19) was found to give the best result. Some good results were also obtained by using Gilson's fluid, recommended by Renner (55), while Flemming's fluids gave bad results, and Juel's fluid proved still less satisfactory. Sections were cut $8-12 \mu$, sometimes $20 \mu$ in thickness. Flemming's triple stain was applied, but very good preparations were obtained by staining with safranin followed by light green, saturated in clove oil. The latter method, which was recommended by Blackman and Welsford (4), was used to the greatest advantage for any developmental stage of the embryo sac, especially for the structures of the egg apparatus, before and after the fertilization, on account of its transparency and clearness, good differentiation of the cell-wall, and the capacity of showing a fine display of the minute plasmic structure. Heidenhain's iron-alum-haematoxylin, Congo red, and orange $G$ were also used for certain special purposes.

Before commencing the study of the embryo sac, the number of the chromosomes in each species and hybrid were counted in the pollen mothercells just in the reduction division as well as in the dividing cells in the young ovular tissue; 7 and $\mathrm{J} 4$, as expected for $x$ and $2 x$ number, were respectively found in them. The pollen and ovular structures were found to be also quite identical in one species with any other of these plants under consideration.

\section{Embryo SaC AND its Development.}

The meiotic phenomena of the embryo sac mother-cell of Oenothera have been repeatedly studied by several investigators, as for instance Geerts (21) in Oe. Lamarckiana and Davis (15) in Oe. bicnnis. The investigation of those interesting phenomena is, however, excluded in the present paper. 


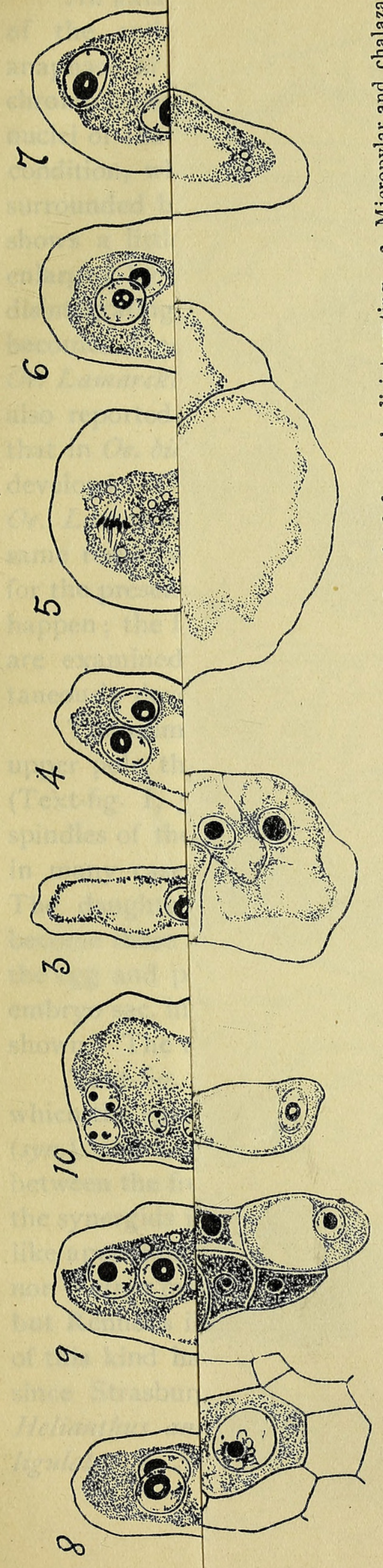

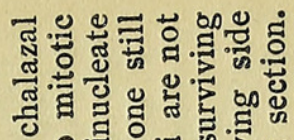

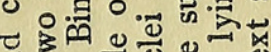
ह ส.

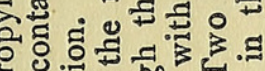
है.

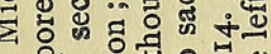
कि

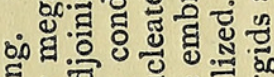
的宗

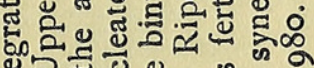
政

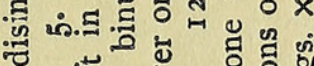

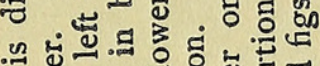

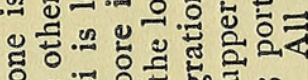
I 0

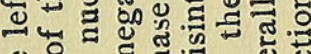

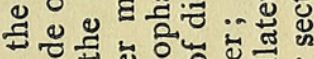
in

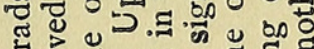

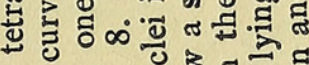

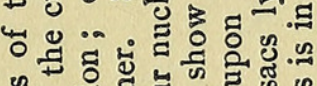

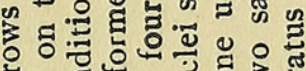
tr

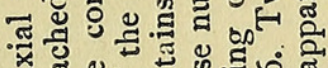
๘ 0 a

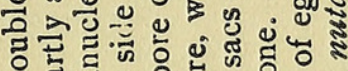
$A$ 을 ¿. . .

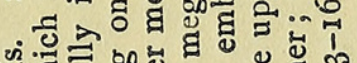
늘

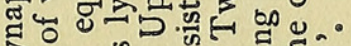
की

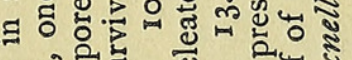

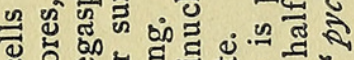
政 के 牙 द

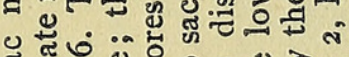

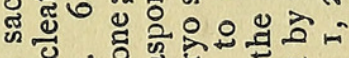
을 0

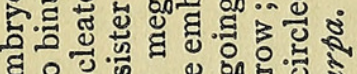
管 of 나에

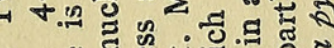

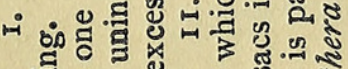

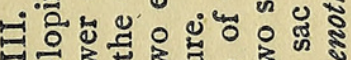

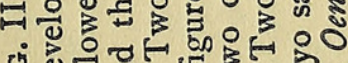
ज्ञ ज्ञ ⿶凵

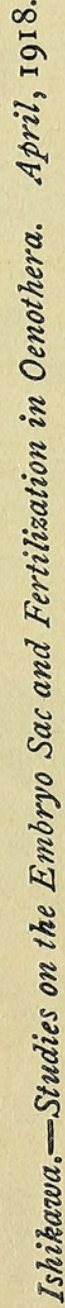

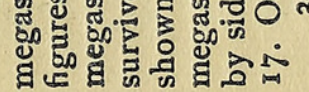




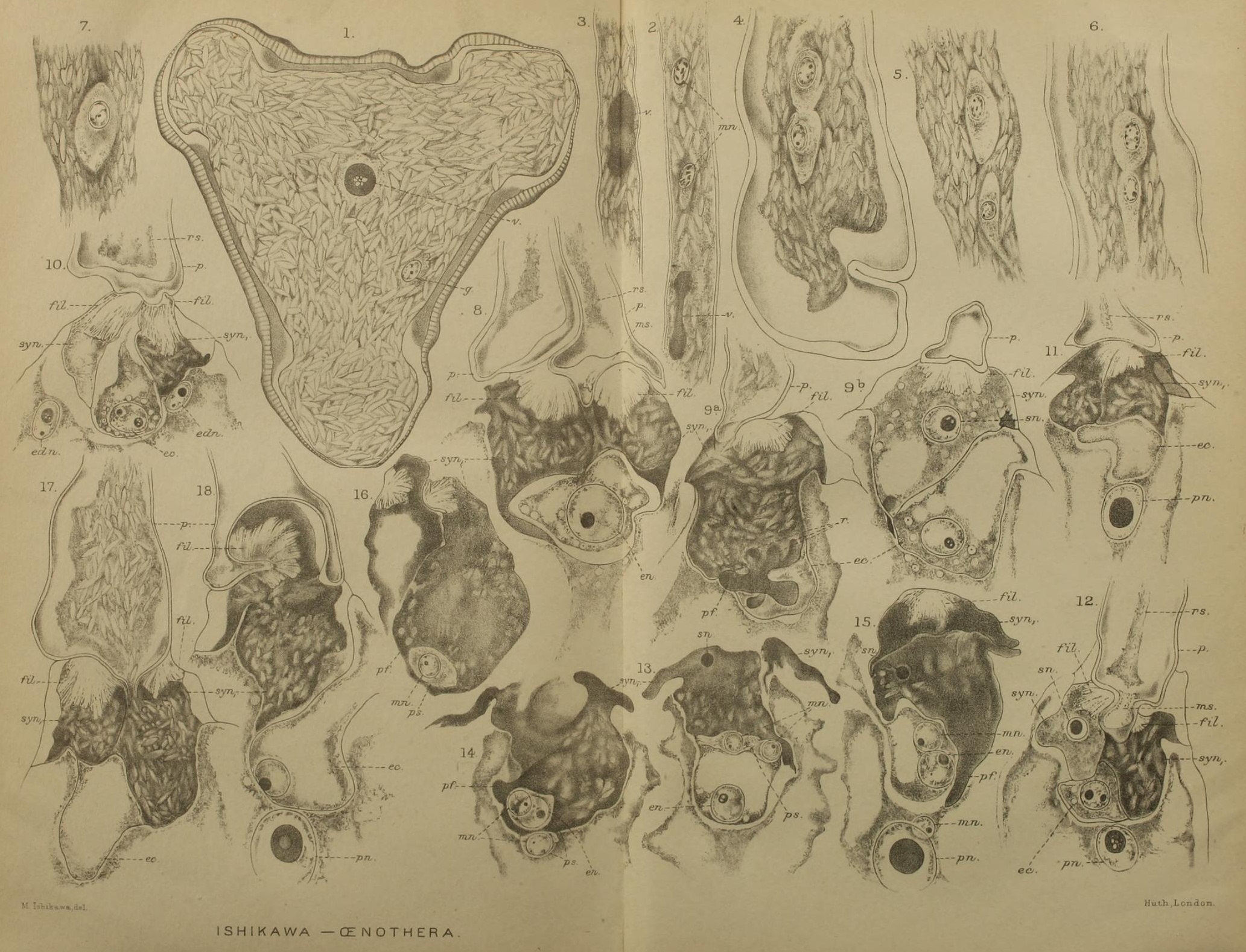





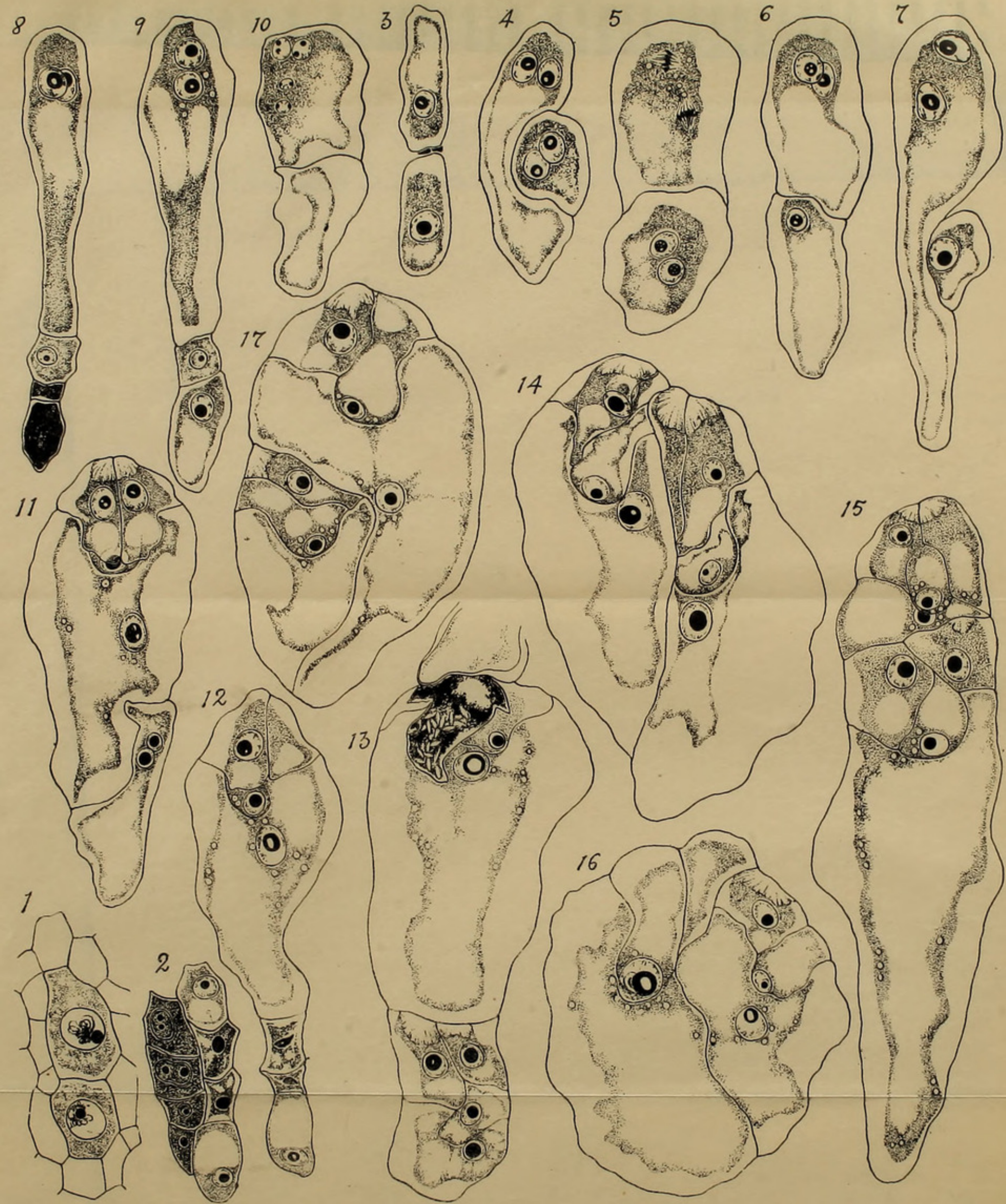

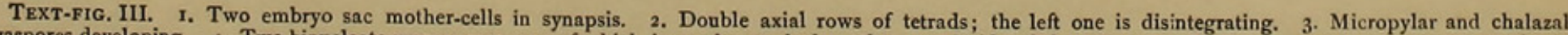

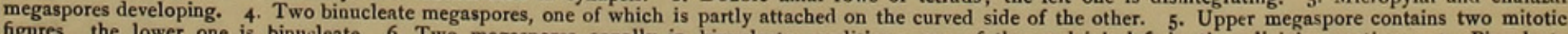

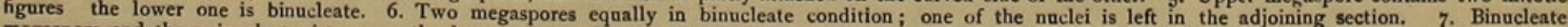

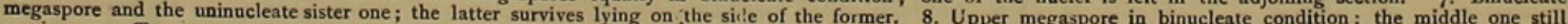

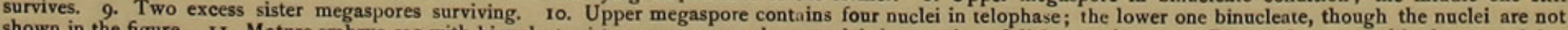

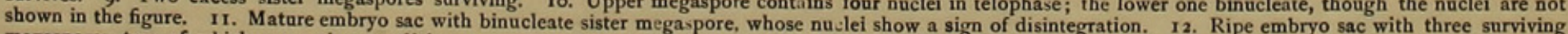

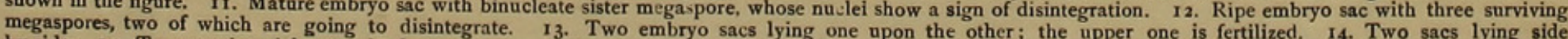

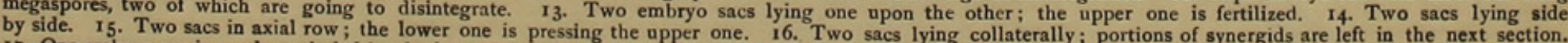
17. One embryo sac is partly encircled by the lower half of the other; part of egg apparatus is in another section. All figs. $x$. 80 .

3-12, 17, Oenothera pycnocarpa. 1, 2, Hybrid 'pycnella'. 13-16, Oe. nutans. 
5

(20)

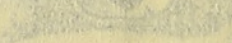

$n^{3}$

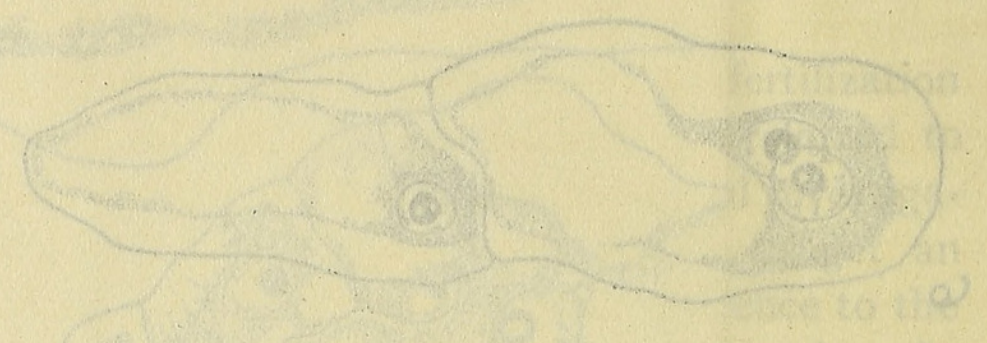

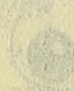

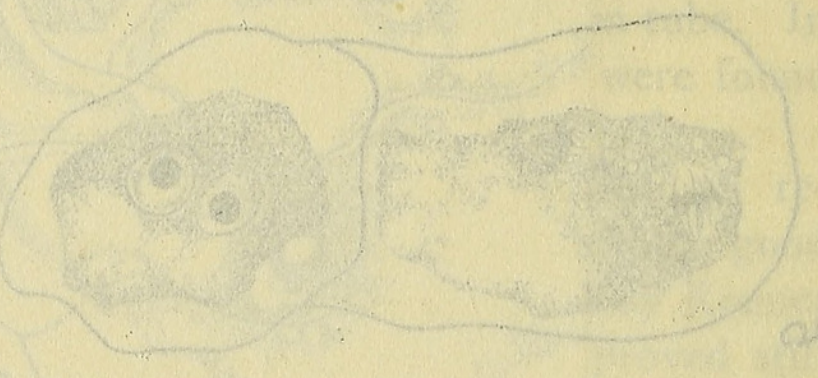

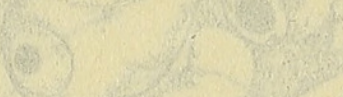

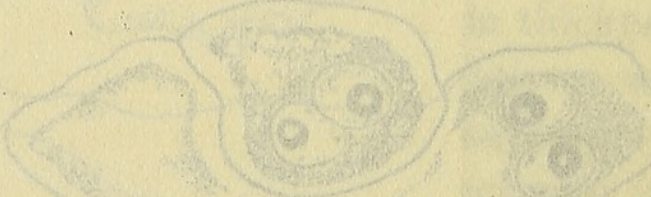

-

$(0)$

$-1$.

(c)

$\sqrt{(6)}$

(vin)

(3)

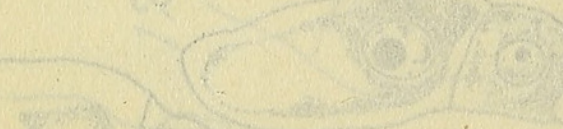

(6)
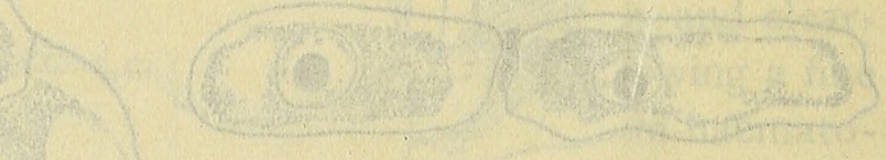

$(2,2)$

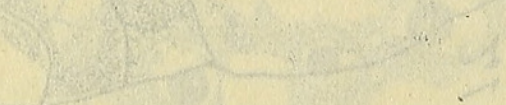
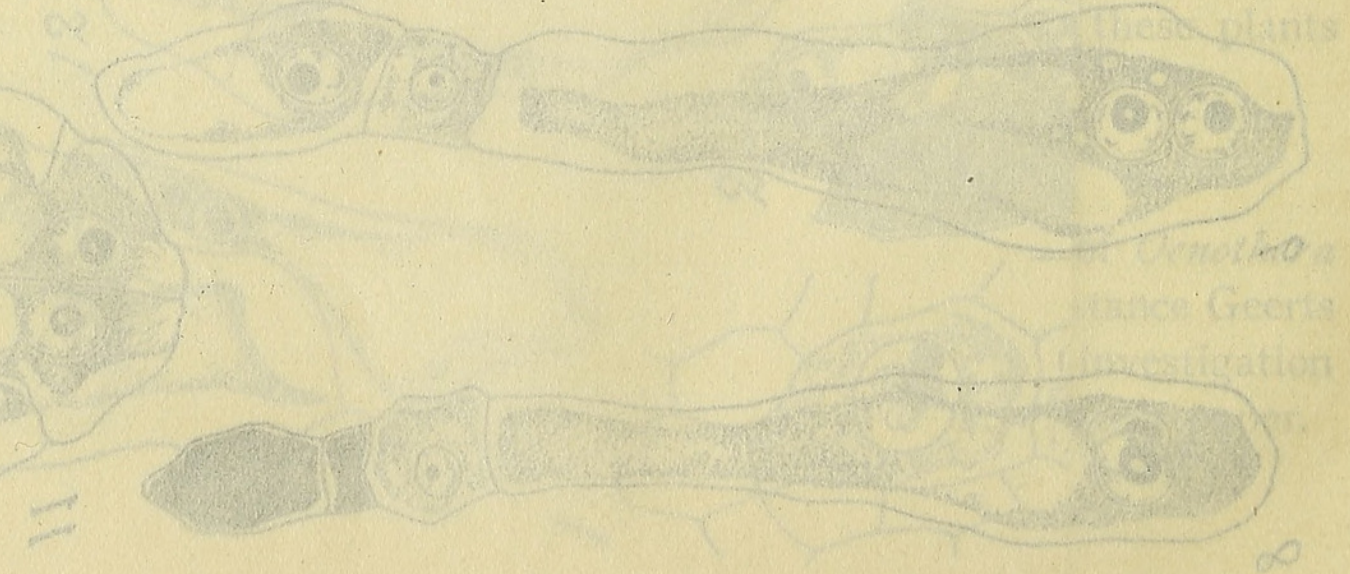
An axial row of four megaspores is formed by two successive divisions of the embryo sac mother-cell. Text-fig. I, I, illustrates the early anaphase of the homotype division, in each nuclear plate of which seven chromosomes are clearly visible. Having finished the tetrad division, the nuclei of the micropylar and chalazal megaspores soon enter into a resting condition, while those of two intervening ones still remain in telophase surrounded by a thin layer of protoplasm (Text-fig. I, 2). Text-fig. I, 3, shows a little advanced stage, the uppermost and lowermost ones being enlarged by vacuolization, and the two intervening ones at the same time disintegrating. Then one of the survivors, whether micropylar or chalazal, becomes functional (Text-fig. I, 4, 5). According to Geerts (21), in Oe. Lamarckiana the uppermost megaspore is functional; the same was also reported by Modilewski (42) for Oe. biennis, while Davis (15) stated that in Oe. biennis often the uppermost, but sometimes the lowermost one develops. On the other hand, Werner (73), who studied Oe. biennis, Oe. Lamarckiana, and several other species of Oenothera, obtained the same result as reported by Geerts and Modilewski. In the species used for the present investigation those phenomena just mentioned above equally happen ; the fact can quite easily be seen if sufficient number of preparations are examined. Both the uppermost and lowermost ones often simultaneously develop, as will be fully described farther on.

The primary embryo sac cell enlarges and the nucleus passes to the upper pole, the lower part being nearly occupied by an enlarging vacuole (Text-fig. I, 5). The nucleus divides twice (Text-fig. I, 6, 7, 8, 9); the spindles of the last division are, if the available space permits, as observed in many cases, perpendicular to each other (Text-figs. I, 8, and III, IO). The daughter nuclei derived from the upper nucleus are destined to become those of the synergids, while those from the lower nucleus become the egg and pole nuclei. Text-fig. I, IO, represents a section of a young embryo sac, in which the arrangement of two sets of the nuclei are clearly shown. The tetranucleate embryo sac is attained in such a way.

Text-fig. I, II, shows a mature typical embryo sac of Oenothera, in which the egg-cell (e.c.) is situated between and just back of the synergids $(\operatorname{syn}$.$) , and only the lower part of the former peeps through the space$ between the free ends of the synergids. The upper free surface of each of the synergids is horizontally notched by an indentation and presents a visorlike appearance (Text-fig. I, II, I 2, ind.). Neither Modilewski, nor Geerts, nor Werner mentions or figures the indentation of the synergids in Oenothera, but Renner's illustrations somewhat suggest its presence. The indentation of this kind has been either reported or delineated for several other plants since Strasburger's description for Santalum album (66); for instance, in Helianthus anmus by Nawaschin (46), in Parnassia pahustris, Saxifraga ligulata, S. Sponheimica, S. cordifolia, Heuchera broxioides, and Drosera 


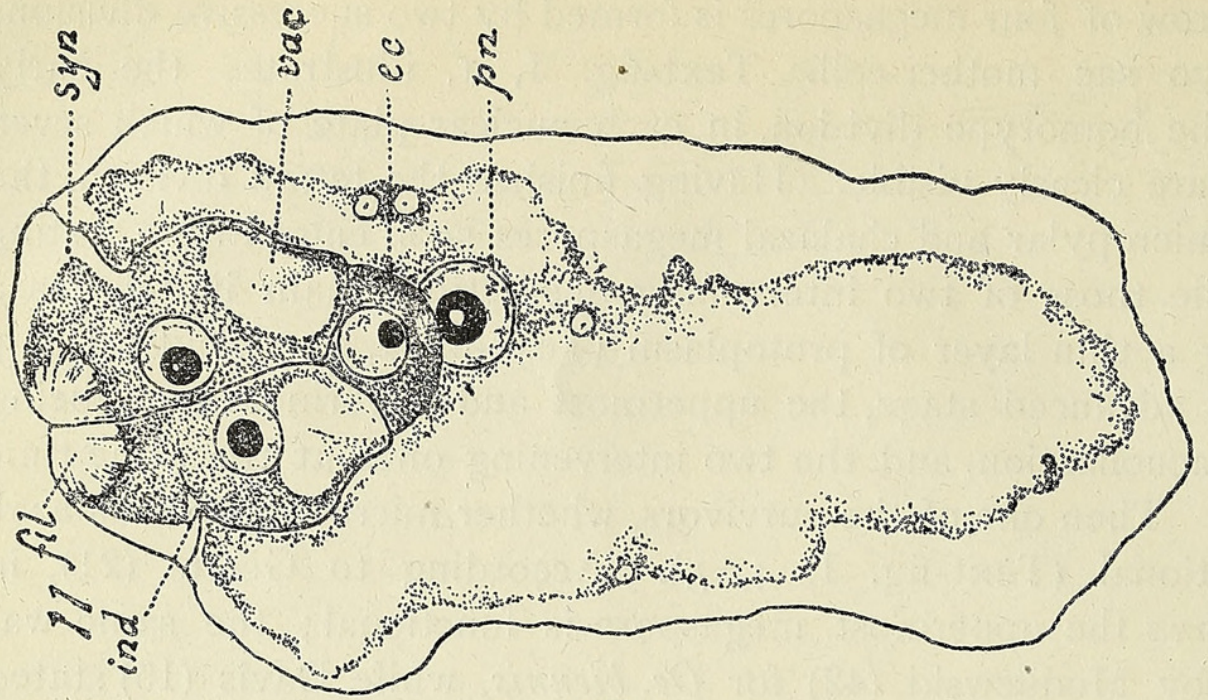

ㅍㅗㅀㅀ

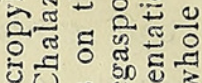

ษ

퓽 की

क को $\approx$ रूं.

…ㄹ.

कू⿻

-. 블

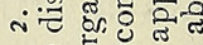

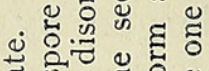

蛋

ฮี हี

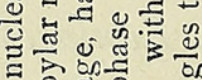

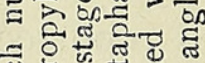

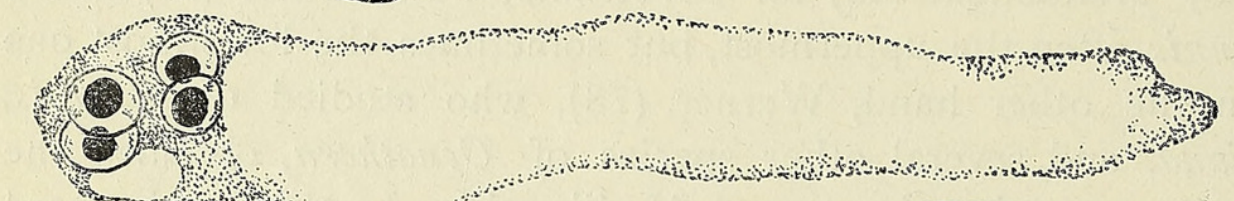

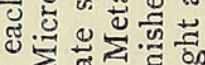

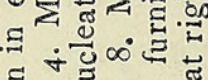

ते

क्ष

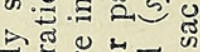

음

ङ

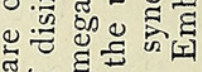

के

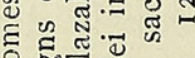

.

응

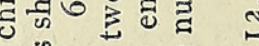

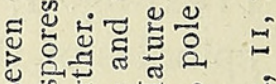

แ

a

क

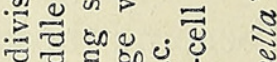

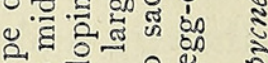

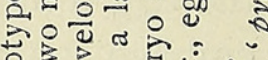

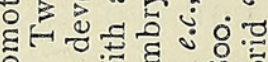

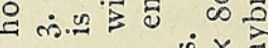

$\Xi$ ๘

$\exists$

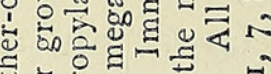

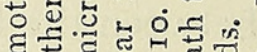

记

N
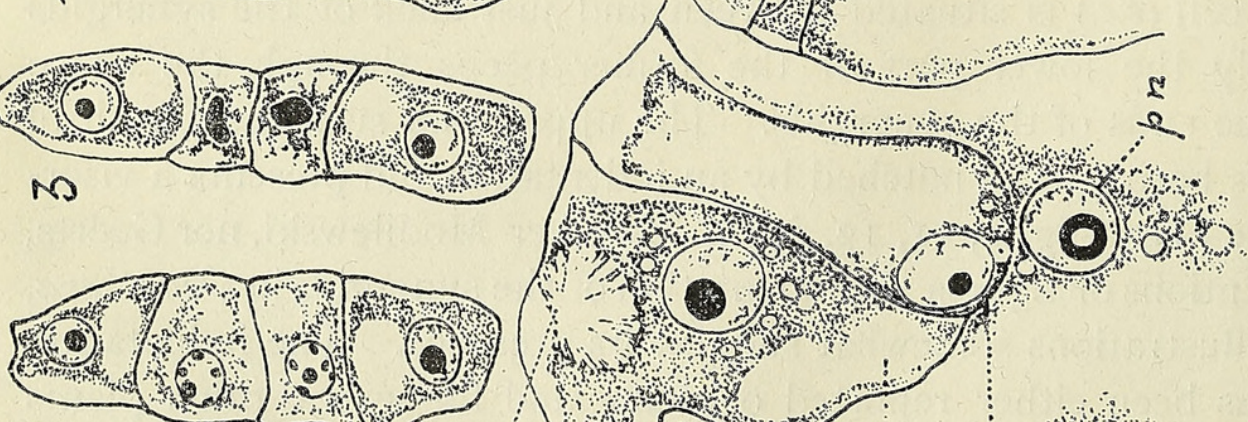

․ำ.을

हैं

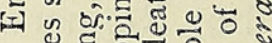

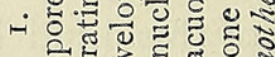

-1 \%

$\infty$

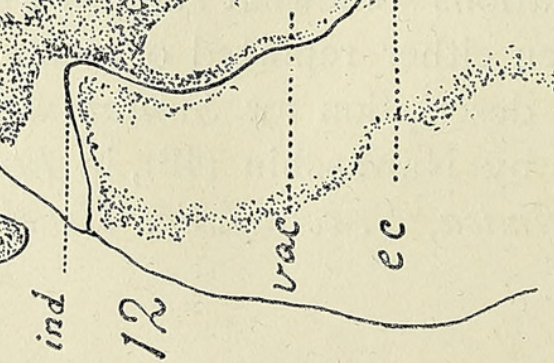

on

ن \&

जٓ बं

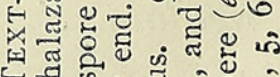

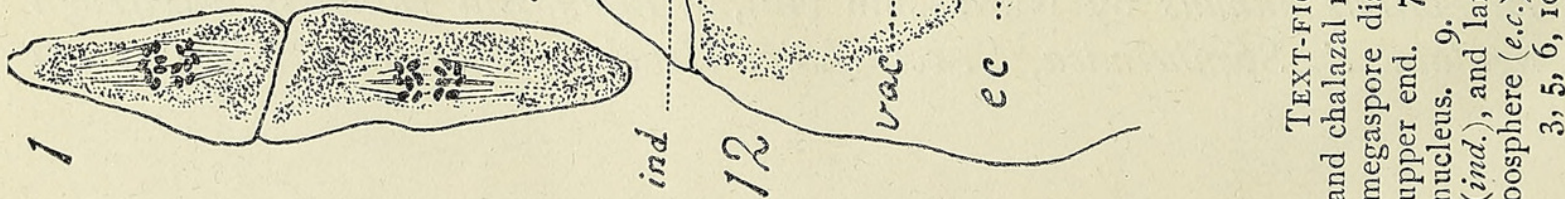


rotundifolia by Pace (51), and in Epilobium angustifolium by Modilewski (42), whose figures are, however, not very clear. The writer has had an opportunity to observe it in the last-mentioned plant (Text-fig. VIII, 4) and also in Circaea quadrisulcata (Text-fig. VIII, 5), as well as in Godetia sp. (Text-fig. VIII, I $a$, I $b$ ), though 4 is not so good as I for illustration. The indentation which is associated with the filiform apparatus, though the reverse is not always the case, has been apt to be overlooked by many investigators, probably owing to the fact that its morphological or physiological significance is scarcely understood.

The apical part of the synergids is occupied by the filiform apparatus, which is a solid mass of a conical shape, and is perforated by a number of minute canals which arise on the basal part and converge towards the apex, as fully described by Habermann (25). As its development had not been faithfully followed, it was quite impossible to fully make out the plexus of immense canals. Only in some cross-sections stained with gentian violet, quite a number of minute pores were clearly made out, which must be the cut ends of the canals. II, I2, fil., Text-fig. I, are intended to show an external appearance of these canals. The following has been compiled to supplement Habermann's list of the plants in which the filiform apparatus is found: Actaea spicata, Podophyllum peltatum described by Huss (30), Helianthus anmus illustrated by Nawaschin (46), Garcinia Kydia, G. Treubii figured by Treub (71), Parnassia pahustris, Saxifraga ligulata, S. Sponheimica, S. cordifolia, Heuchera broxoides, Drosera rotundifolia, Atmosco texana, and Gyrostachys gracilis described by Pace $(51,51 a$, and 52), Myricaria germanica by Fristendahl (18), Butomus umbellatus by Holmgren (29), Trifolium pratense by Martin (40), Myosurus minimus by Tchernoyarow (70), Ottelia lancifolia by Palm (53a), and finally Godetia sp., Gaura Lindheimeri, G. parviflora, Epilobium angustifolium, and Ludwigia prostrata observed by the present writer, as shown in Text-fig. VIII, I $a, \mathrm{I} b, 2,3,4$, II. In the mature sac of Oenother $a$ and some other plants examined, all belonging to the Onagraceae, a large vacuole usually appears below the nucleus in each of the synergids, which is clearly figured in Text-figs. I, I1, I2, vac., and VIII.

The pole nucleus $(p . n$.$) , which is almost in contact with the oosphere,$ increases markedly in size, and is provided with a large nucleolus. As a rule, in the eight-nucleate embryo sac, the secondary embryo sac nucleus is very voluminous, owing, of course, to the fusion of the two polars; but in the case of Oenothera the single polar without any additional nucleus acquires a conspicuously large volume. This fact suggests that the polar shares the nutritive function, acting as the antipodals, though the chromatic condition of the nucleus is too normal for the one in such an active condition.

In the nucleolus of the polar, one or several vacuoles are always present, which are often replaced by a crystalline structure, and the same is 
the case with the synergid nucleus. It may perhaps be the proteid crystalloid, though its characteristic reactions could not be brought about by chemical reagents, due to the influence of the fixing fluid. It is, however, interesting to notice the fact that all transitional forms from a spherical vacuole to the crystalloid may be followed; anyhow those structures may. need a further investigation. The occurrence of the crystal in the nucleolus has been described by Leitgeb for Galionia candicans, and later by Digby (16) in the same plant, who states that the crystal was probably originated from the nucleolus, and appeared to stain with chromatin dyes. Reed (56) is another investigator who found a similar substance in Allium Cepa; according to this author such structures were observed during the development of the spireme, at the end of which they disappeared and seemed to be stained no longer. Dr. Kuwada personally informed the writer that he also found it in the nucleolus of the pollen mother-cell of Zea May's.

Text-fig. I, I2, is another view of a similar embryo sac, cut at right angles to the median line of the embryo sac represented in Text-fig. I, II. The whole of the oosphere is represented, but one of the synergids is left in another section. Here both the filiform apparatus ( $f l$. .) and the indentation (ind.) of synergids are also clearly shown. A large vacuole occupies nearly the whole space of the egg-cell, in the lower end of which the nucleus lies against the cell-wall. Generally the nucleus of the egg-cell is smaller than that of the synergid, though such a relation is not well shown in this figure. Members of the egg apparatus are clearly separated by a distinct cellulose membrane from one another as well as from the wall of the embryo sac. The lower end of the oosphere is peculiar in this respect, that it possesses neither cellulose nor pectin membrane so far as is indicated by chemical reagents. Plasmolysis does not occur in this portion, while it is clearly discernible in the remaining part; the lower end may probably be bordered by a plasma membrane. As clearly shown in the figure, the apical end of the embryo sac is occupied by the synergids, and the egg-cell hangs down from a position at a distance below the terminal end of the sac. Spherical starch grains were generally found scattered in the plasma sheet of the sac as well as in the lower part of the oosphere, but in a few cases they have been observed as occurring also in the synergids (Text-figs. I, 12, III, I5; Pl, VII, Fig. 9, $b$ ). Proteid and glucose were detected in the vacuole of the synergid by Habermann (25), who concluded that such proteid and hexose flowed out through the canals of the filiform apparatus, causing a chemotropic reaction of the pollen-tube. The absence of starch grains in the synergid seems to be correlated with the presence of glucose in the vacuole, the glucose being a mere disguise of the starch.

Among over 500 selected preparations which were closely examined, four sections were found in which small rod- or biscuit-formed structures 
were observed lying in the egg-cells. The materials for these sections were partly fixed with Bouin's fluid and partly with Benda's fluid.

I, 2, Text-fig. II, which were drawn from the preparations stained with iron-alum-haematoxylin, illustrate two cases in which these structures are found. In the first figure the egg apparatus is shown, in which the synergid darkly shaded is plumped by the attack of the pollentube, while the other is shrinking. Between those is situated the fertilized egg-cell, two synergids containing a small number of the structures in question, which are scattered between the cell-wall and the righthand side of the nucleus. The second figure represents a section of the oosphere showing two groups of those structures, each small body of which makes a pair and looks as if the couple has just been .

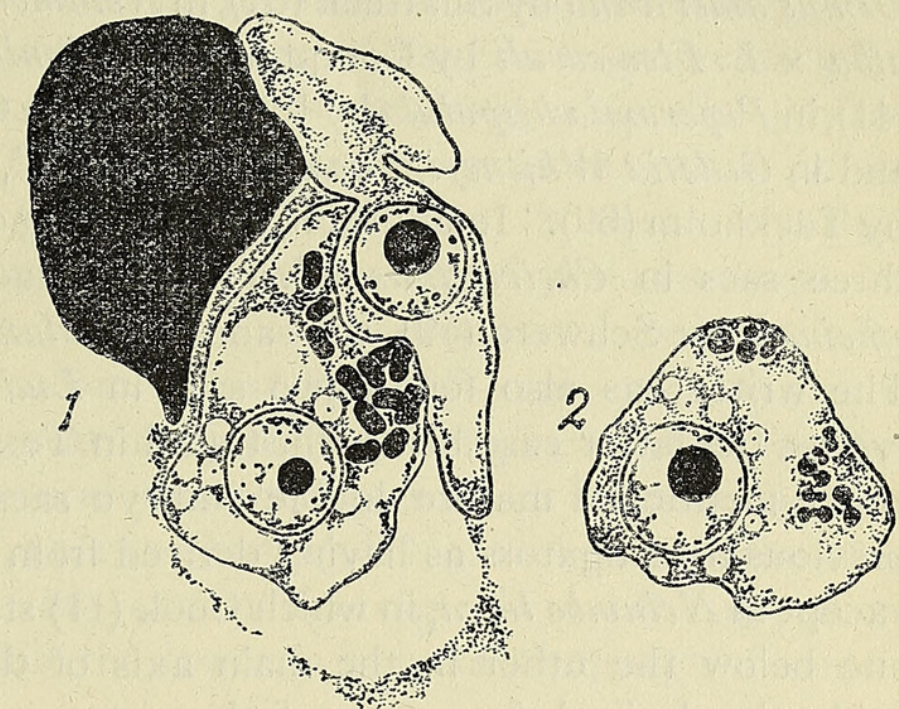

TexT-FIG. II. I. Hybrid 'pycnella'. Egg apparatus showing chondriosome-like structures in a fertilized egg-cell. 2. Oenothera mutans. Oosphere containing two lumps of chondriosome-like structures besides some starch grains. Both figures $\times 1,300$.

derived from a common source by division. Unfortunately, the specimens are not sufficient for a more detailed examination. B But judging from all the appearances these small bodies seem to be something like chondriosomes.

\section{Doubling of Embryo Sac.}

Among the Angiosperms the occurrence of the excess embryo sac mother-cell is commonly known. Oenothera is not exceptional in this respect. Geerts (21) reported such a case in Oe. Lamarckiana; and the same was also described by Täckholm (68) for Oe. biennis, in which two rows of the tetrads occurred lying side by side. Besides, he met with four or five definitive archesporial cells in the closely related genus Lopezia, and always several mother-cells in Godetia and in Clarkia (69). Text-fig. III, I, shows two embryo sac mother-cells in synapsis lying one upon the other. Text-fig. III, 2, represents two rows of the tetrads, one set normally developing and the other showing a sign of disintegration. Several other cases have been studied, with a result that only one of the mother-cells or its derivatives is functional.

Many cases have been reported where several primary embryo sac cells, derived from the different mother-cells, start forming the embryo 
sacs; but, as to the twin sacs, only few examples have been given. Coulter and Chamberlain (13) summarized the cases known at that time: two ripe sacs in Lilium candidum, Salix, Fuglans cordiformis, Delphinium, and Senecio, and two or more sacs in Fagus, Corylus, and Carpinus. Since their publication several other examples have been reported: mature twin sacs in Ulmus americana by Shattuck (61), in Nelumbo lutea by Cook (11), in Lychnis alba $\times$ L. Flos-cuculi by Compton (9), in Smilacina racemosa by McAllister (41), in Peperomia hispidula by Johnson(32), in Gastrodia elata by Kusano(36), and in Godetia Whitneyi, Fuchsia 'Marinka', and F. 'Émile de Wildeman' by Täckholm (69). In addition, the following cases have also been reported : three sacs in Cheiranthus Cheiri by Schacht (57), two in Taraxacum officinale by Schwere (59), the same in Balanophora globosa by Lotsy (37). The writer has also found two sacs in Ludwigia prostrata and Jussiena repens, the latter case being illustrated in Text-fig. VIII, $9 a, 9 b, 9 c$. The above-mentioned mature double embryo sacs have been explained by the previous investigators as having derived from two independent mother-cells, except in Nelumbo lutea, in which Cook (11) stated that 'two sacs were found one below the other in the main axis of the ovule. The extra sac was evidently derived from one of the sister megaspores.' This is the only example of mature twin sacs originated from two sister megaspores, though we know many examples in which all or some of the sister megaspores develop as far as either a bi- or quadrinucleate condition is reached, but only one of the original megaspores becomes a mature embryo sac.

In Oenothera studied by the writer the twin sacs commonly occur, sometimes lying side by side (Text-figs. III, 14, I6, and IV), sometimes one upon the other (Text-fig. III, I3, 15). It seems to be the general rule in these plants that of four megaspores the two interjacent ones first disintegrate, then one of the survivors follows the example. But, if both survivors simultaneously begin to develop, the twin sacs may ultimately be attained. This is just the case with Oenothera. No case has been observed, however, in which more than two megaspores had developed. 3 and 5 , Text-fig. III, show two successive stages, the former of which represents two growing megaspores, and the latter similar ones in a binucleate stage, the micropylar one of which is ready for a tetranucleate state. Text-fig. III, 6, illustrates two developing megaspores in a binucleate condition, though one of the nuclei in the lower megaspore is left in the next section. These structures generally give rise to twins, as shown in Text-fig. III, I3, I5. Geerts (21) states that he once observed an embryo sac which contained eight nuclei, and that in the middle portion of the sac a partition line was clearly visible. Though he did not give any figure, the sac observed by him must have been in the same condition as those described above.

In Text-fig. III, I3, the upper sac, which is already attacked by the pollen-tube, is pressing the lower one, while the filiform apparatus is developed 
in each of them, though the whole aspect cannot be included in this section. In Text-fig. III, ${ }_{15}$, the lower one, whose polar is in the adjoining section, is gaining, and the filiform apparatus are developing in both of them. The dislocation of the megaspores often takes place in the course of their development (Text-fig. III, 4, 7), resulting in the formation of the condition delineated in Text-fig. III, $\mathrm{I} 7$, in which the smaller one appears as if partly embedded in the larger sac. If the above-stated dislocation proceeds farther and the inferior one remains, two embryo sacs attain a parallel position (Text-figs. III, I4, I6, and IV). Often the lower megaspore remains in unior binucleate state, as shown in Text-fig. III, II, I2. A similar condition has been reported as occurring in a related species, Lopezia coronata, and in some others by Täckholm $(68,69)$. The writer has found the same phenomenon in Ludwigia prostrata (Text-fig. VIII, I0); such a case is, however, known to occur in a great many plants belonging to other families. $8,9,10$, Text-fig. III, show several younger stages which correspond to the cases as shown in Text-fig. III, I I, I 2. Text-fig. III, 9, shows one of the intervening megaspores still surviving, and in Text-fig. III, 10, the upper one is in a tetranucleate stage, while the lower is binucleate, though the nuclei are not visible in this section.

As to the fate of the excess embryo sac, nothing conclusive can be stated, owing to the lack of the material, except that it may disintegrate sooner or later when the ovule is entered by a single pollen-tube, or it may be visited by a pollen-tube (Text-fig. IV), when more than one pollen-tube penetrates the ovule.

In Text-fig. IV, which has been reconstructed from three succeeding sections, ideally cut, the sac on the right-hand side is just before the fertilization, while the other is in contact with the pollen-tube. This figure suggests possibility of fertilization in both of the embryo sacs. Schwere (59) working on Taraxacum officinale found a case of twin embryo sacs, each giving rise to a normal embryo; such was also the case with Gastrodia elata studied by Kusano (36), in Lychnis alba $\times$ L. Flos-cuculi by Compton (9), and in Ulmus americana by Shattuck (61), though in the latter two cases it was not retraced farther up to the embryo sac formation.

The persistency of more than one megaspore in Oenothera, which is situated in the higher rank among the Polypetalae, shows the atavistic inclination of the young gametophyte caused by an evolutional tendency.

\section{Male Gametophyte.}

A full description concerning the development of the pollen mothercell of Oenothera has been given by Geerts, Gates, and Davis; the further growth of the pollen, especially the development of the pollen-wall, has been faithfully followed by Beer (3). The ripe pollen grain, just before shedding, contains a vegetative nucleus (Pl. VII, Fig. I, $v$ ) in the centre 
and a generative one (Pl. VII, Fig. I, $g$ ) in the peripheral portion. The former is presented as a spherical chromatin mass showing a sign of disintegration, and embedded in a plasma mass, while the latter is smaller and ellipsoidal, and is surrounded by a thin plasma sheet. The rest of the contents is impregnated with immense numbers of hyaline, fusiform corpuscles (Pl. VII, Fig. I), which scarcely stain with the usual chromatin dyes, so that they are apt to be overlooked, and the whole contents of the pollen grain are taken for an alveolar plasma mass. These corpuscles are typical fusiform or oblong ellipsoidal in shape, with acute or often obtuse ends, and show the reaction characteristic to starch by treating with iodine solution. Starch grains were often found in pollen grains of many plants ; they were spherical, ellipsoidal, or rod-like, but not fusiform as in the case of Oenothera, although Guignard (24) reported that there were fusiform starch grains in the pollen and pollen-tube of Najas major. Thus, it was found necessary to test whether they were really starch grains or not. But, having no fresh material at hand, Oenothera odorata was used for this purpose, whose pollen grains are quite identical with those of Oe. pycnocarpa and of Oe. mutans in every minute respect. The fresh pollen grains were crushed under the cover-glass, and several reagents were applied upon them. The result was as follows: By adding iodine solution the corpuscles in question turned blue, while by heating they became decolorized and swollen; they swelled also when treated with chloral hydrate; they disappeared after standing 6-20 hours in I-2 per cent. solution of 'Takadiastase', keeping them in $60^{\circ} \mathrm{C}$. These reactions leave no room for doubt that they are no other than starch grains.

The pollen-tube reaches the embryo sac at least in 48 hours after pollination. In an experiment, some pollen-tubes have arrived in the ovules in 53 hours and 30 minutes; in this case some eggs were already fertilized or just being done, but some embryo sacs were laid free from invasion of tubes. The plasm of the pollen-tube contains a large number of starch grains which are fusiform, ellipsoidal, or spherical, but not so uniform as observed in the pollen grain; this fact suggests that starch grains undergo some chemical changes, owing probably to the use as nutrition of the tube. Pl. VII, Fig. 2, illustrates the lower portion of the tube travelling through the stylar tissues, and carrying a disintegrating tube nucleus $(v)$ and two male nuclei $(m . n$.) which are in the last telophase. In the upper portion of the tube, though not shown in the illustration, a series of stoppages or cross septa are laid down, which showed the reaction characteristic to callose, being stained red with corallin-soda. Nodal swellings and branching of the tube were often observed; the latter case was always found in the micropylar portion, and made it difficult to distinguish whether two different tubes or a pair of branches were present. The wall of the tube is never found of a uniform thickness, particularly in the apical portion. 
Two sperm nuclei were often found in the lower end of the tube, which lay just upon the embryo sac, but the vegetative nucleus was not associated with them, though Modilewski (42) observed and delineated both. Much attention was focused upon this question, but no vegetative nucleus happened to be found there at all. It may have been suspended at one of the nodal swellings of the tube, because it is often the case that the tube nucleus is found staying in such a place. Or it may have become absorbed in the tube plasm before it reached the embryo sac. The male nucleus is ellipsoid or ovoid, containing few chromatic masses besides one to several small nucleoli, and is surrounded by a distinct plasma sheath which presents itself as elliptical or lenticular in form (Pl. VII, Figs. 4, 5, 7). In some cases both of the nuclei are found embedded in a common plasma sheath (Pl. VII, Fig. 6). It is interesting to notice that a greater quantity of plasm is found in front of than behind the male nucleus. This fact suggests that the nucleus is dragged by the plasm, causing the movement of the male cell towards the embryo sac. Blackman and Welsford (4) noticed, in Lilium, that one of the male nuclei which was destined to fuse with the egg nucleus was smaller than the other. This was not the case in Oenothera, and both the nuclei are nearly equal in size. Neither Modilewski (42) nor Geerts (21) has described or figured the plasma sheath in Oe. Lamarckiana and in Oe. biennis. In a paper on Myosurus minimus, recently published by Tchernoyarow (70), there are many good illustrations of male nuclei, embedded in a distinct plasma sheath in the pollen-tube as well as in the plasma mass, which flowed out of the synergids, and spread upon the oosphere. According to this observer, the male nuclei shed the plasma sheath before the fusion, as in the case of Oenothera. The cases illustrated in his figures agree very well with those observed by the writer in Oenothera, except that two male nuclei always lie in a common plasma sheath.

\section{Fertilization.}

On reaching the apical end of the sac, the pollen-tube proceeds to the upper part of the synergid, but never directly passes to the egg-cell, though the latter is situated so close to the tip of the former. It has been observed only once that the tube happened to come to the upper end of the egg-cell, but, without visiting the latter, turned the way to the apex of the filiform apparatus. On arriving at the synergid the pollen-tube pierces the filiform apparatus first of all, and generally makes its way through the border line of two adjoining apparatus (Pl. VII, Figs. 8, 10). As stated above, Habermann's conclusion is that the chemotropic reaction of the pollen-tube is induced by glucose and proteid, which are poured out through the canals of the filiform apparatus from the store of the vacuole in the synergid. It just explains the behaviour of the pollen-tube of Oenothera. In some cases the end of the tube expands just upon the filiform apparatus, and the 
narrowed tip penetrates the apparatus (Pl. VII, Figs. I2, I7); in other cases the tube ramifies at the contact surface, reminding one of the pseudopodia of Amoebae or clasping fingers, and some of the branchlets proceed farther (Pl. VII, Fig. I 8). In such a case it often causes dislocation of the filiform apparatus $(f i l$.$) , which subsequently becomes smothered by the con-$ tents of the attacked synergid (syn.) flowing out. The tip of the pollentube has no special apparatus for pouring out its contents. A small pore seems to be in preparation for a time, probably by the action of certain enzymes, such as cytase and pectinase, secreted by the male cell, and acting upon cellulose and pectic substance, of which the wall of the tube and filiform apparatus are composed. Though it is a mere supposition, the same enzymes may attack next the filiform apparatus for the passage of the tube, and then act upon the wall of the invaded synergid, which thus becomes actually perforated, as will be described later on. The contents of the tube are poured into one of the synergids (Pl. VII, Figs. IO, I2), or often into both of them (P1. VII, Figs. 8, II, 14, I 7 ; Text-figs. IV, VII, 3), probably owing to the accidental position of the tube end, so that sometimes it causes the enzymes to act upon the walls of both synergids.

The plasm containing starch grains in the pollen-tube is poured into the attacked synergid (syn.) as shown in Text-fig. VII, I-3; P1. VII, Figs. 8-I2, 17 , 18 ; especially Fig. I 7 shows the critical moment of the intrusion of those expelled grains. For this reason the grains serve as a clue to trace the contents of the tube. Iodine solution is the best reagent for this purpose. The intrusion of starch grains from the pollen-tube has already been mentioned and illustrated as occurring in Najas major by Hofmeister (28) in $185^{8}$. He also observed so early as 1847 the migration of starch corpuscles from pollen grains to pollen-tubes in several other plants, especially in Oenothera, Godetia, and Boisduvalia (26).

The invaded synergid becomes much swollen with the additional protoplasm, and the contents suddenly get chromatic, but starch grains inside are still perceptible. The wall of the synergid bursts, with the result that the mixed contents flow out upon the lower part of the oosphere, which is thus covered by them for a while. Pl. VII, Fig. $9 a$, represents a side view of an attacked synergid $\left(s y n_{\cdot 1}\right)$ : the contents $\left(p . f_{.}\right)$are just going to spread over the oosphere (e.c.) through the several rents $(r$.) on the lower side. Fig. $9 b$ is another section obtained from the same sac, showing the other sound synergid (syn.) and the egg-cell (e.c.), the latter of which is just ready for fertilization. Text-fig. IV clearly illustrates an advanced stage : in the right-hand one of the twin sacs, the oosphere is totally covered with the contents $(p . f$.$) of the invaded synergid (\operatorname{syn}$.$) , while the disorganized synergid$ nucleus is seen as a spherical chromatic mass $(s . n$.$) , and two male nuclei (m . n$. embedded in a hyaline plasma sheath (p.s.) are clearly visible, through which the egg nucleus $(e . n$.$) is discernible. Figs. 14$ and $\mathrm{I} 6, \mathrm{Pl}$. VII, represent 
some more examples of the same stage as the latter. Fig. I3 illustrates a similar case, showing two male cells $(m . n$.$) and egg nucleus \left(e . n_{0}\right)$ in the oosphere, the lower end of which has been cut off obliquely.

It appears that two sperm cells always pass through the synergid before they reach either the egg-cell or the pole nucleus, although no direct proof

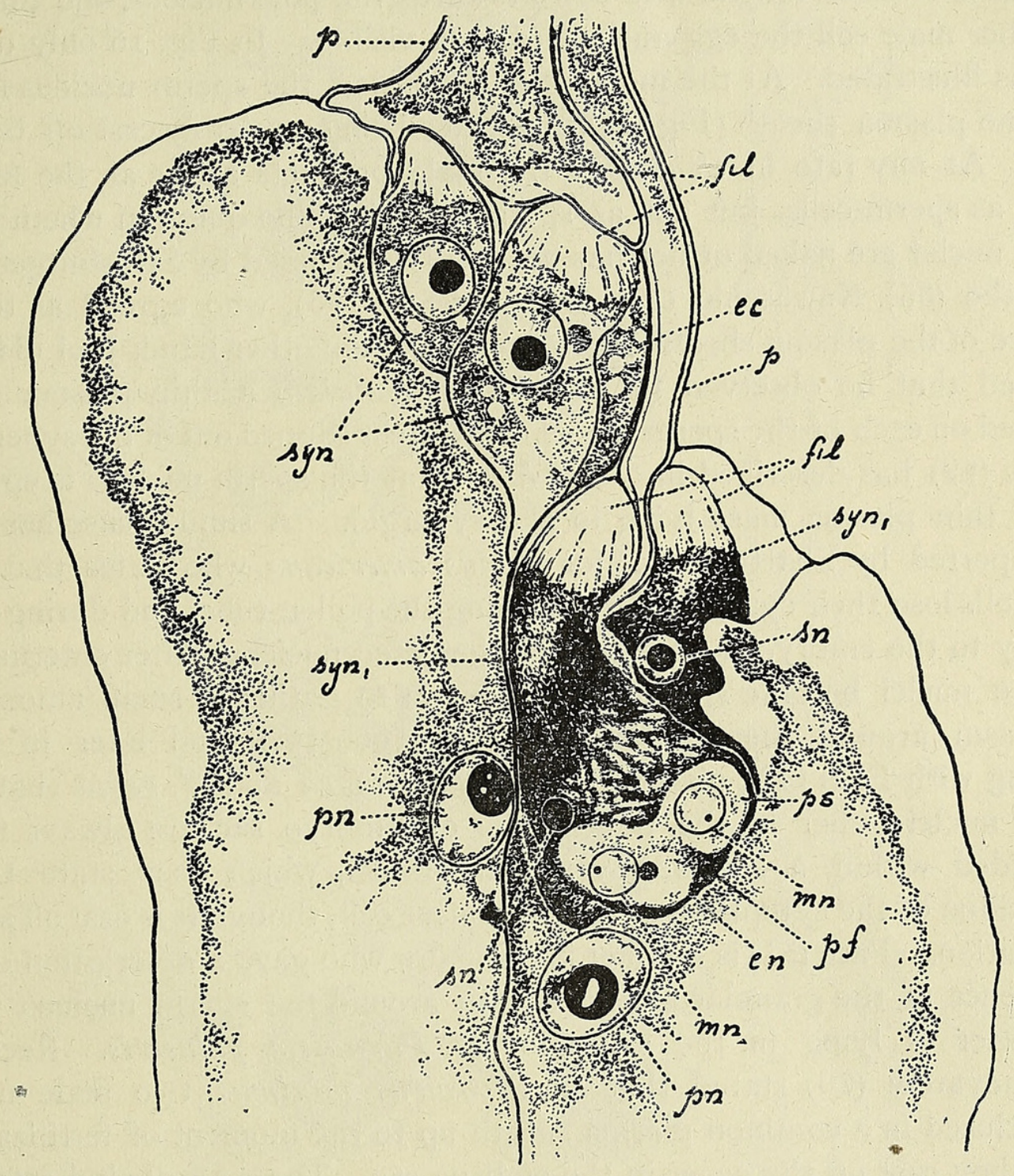

Text-FIG. IV. Twin embryo sacs of Oenothera mutans fertilized by Oe. pycnocarpa, both of which are attacked by pollen-tubes $(p$.$) ; the right-hand one has already been penetrated by the tube and$ plasma flow $(\not p . f$.$) from the synergid (s y n \cdot 1)$ is spreading over the oosphere ; on the lower end of the latter two sperm nuclei $(m . n$.) lie surrounded by a distinct plasma sheaf (p.s.), through which egg nucleus $(e . n$.$) is visible. syn., sound synergid; fll., filiform apparatus; e.c., egg-cell; s.n., synergid$ nucleus; $p . n$. , pole nucleus. $\times 1,300$.

has been obtained. When perched upon the egg-cell, two sperm nuclei are clearly seen, for each of them is covered with a hyaline plasma sheath, which is stained well with light green, while the poured plasma mass is very chromatic and is stained dark red with safranin. Pl. VII, Figs. I3 and 14, and Text-fig. IV were drawn from the preparations stained with a combina- 
tion of safranin and light green, on which every detailed structure is shown up most brilliantly. Fig. I 6 is delineated from a section stained with a combination of light green and iron-alum-haematoxylin ; the plasma sheath (p.s.) stained with the former is beautifully differentiated from the surrounding plasma mass $\left(p . f_{.}\right)$, which is stained dark with the latter. In Fig. I 3 and Text-fig. IV two male cells are lying side by side, while in Fig. I4 one of them is situated a little way down towards the pole nucleus, and through the other male cell the egg nucleus (e.n.) is visible. In Fig. I6 only one of them is illustrated. At the moment of the fusion, the sperm nucleus $(m . n$.) bears no plasma sheath (Fig. I5), the latter being probably cast off beforehand. At any rate in Oenothera the male products arrive at the female organ as sperm-cells, but not as sperm nuclei. The question whether the sperm nuclei are naked or not has been fully discussed by Strasburger (67), Körnicke (35), Nawaschin (47), and Welsford (75), who agreed as to the absence of the plasma sheath in Lilium. On the other hand, Juel (34) has reported that he observed in Saxifraga gramulata a thin plasma mass, attached on each of the sperm nuclei, which just slipped out of the synergids. Němec (49) has described in Gagea lutea that the sperm nucleus is covered with a thin plasma mass lying in the synergid. A similar case has been also reported by Shattuck (61) for Ulmus americana, who states that 'the male cells lose their cytoplasm on entering the pollen-tube, and during their journey to the embryo sac are simply elongated nuclei. After entering the sac the nuclei become spherical and begin to gather a small amount of cytoplasm around them.' Nawaschin in 1909 (46), and later in 1915, working with Finn (48), observed in Fuglans nigra and F. regia that two sperm nuclei either in the pollen-tube or embryo sac are always found embedded within a common vesicular sheath, which they state to be the residue of the cytoplasm of the generative cell, though it is cast off before fertilization. Pace (51) is another investigator who gave a description of the occurrence of the granular plasma sheath around the sperm nucleus, when the latter is lying in the synergid, in Parnassia palustris. Recently Tchernoyarow (70) stated that in Myosurus minimus two male nuclei are enclosed in a common plasma sheath up to the moment of fertilization, when they cast off the cover in the embryo sac. These results indicate that possible existence of such a sperm-cell may be detected, if closely examined, in not a few families of the Angiosperms.

Modilewski (42) has reported entry of the vegetative nucleus into the embryo sac, though no trace of such has been found by the writer in the sac, nor even in the end of the tube just before shedding, as already stated above. Only the degenerating synergid nucleus has often been observed as a chromatic globule in the attacked synergid, as shown in Pl. VII, Figs. I3, I 5, s.n., and in Text-fig. IV, s.n. Although it is in a degenerating condition, the vegetative nucleus is quite different from the chromatic nucleus of the 


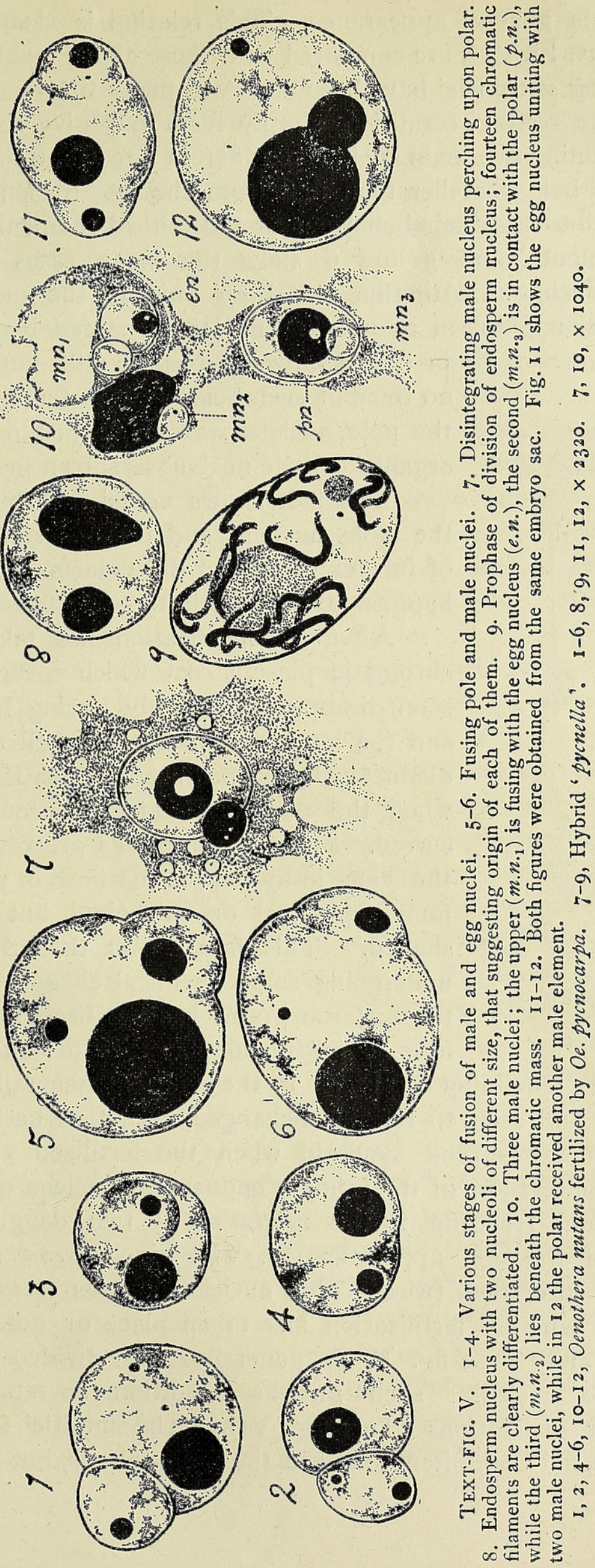


synergid in its general appearance. This relation is clearly perceivable if Figs. 2, 3, v., Pl. VII, are compared with those above mentioned.

The fusing sex nuclei have been observed many times. They come in contact in the resting condition, simply fuse, and give rise to a larger nucleus containing two main nucleoli of different sizes, that derived from the male nucleus being smaller than that from the egg nucleus. I, 2, 3, 4, Text-fig. $V$, illustrate their behaviour at the critical moment of the fusion of both elements, and 5 and 6 show the same cases in the polar and sperm nucleus. Attention has been paid to the question of the plasma inclusion between two fusing nuclei, as stated by Brown (5) in Peperomia Sintensii or in Gagea lutea by Nèmec (49), but in Oenothera

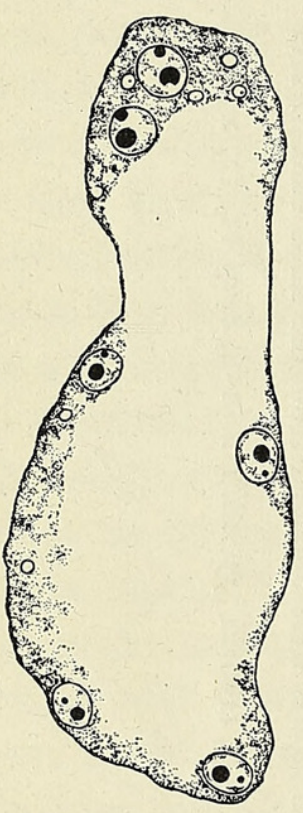

TEXT-FIG. VI. Section through plasma sheet with sixteen endosperm nuclei, showing two nucleoli in each of them. $\times 450$. no trace of such bearings was found. Sometimes the pole nucleus was found just receiving a disorganizing male nucleus as shown in Text-fig. $\mathrm{V}, 7$.

This fact shows occasional disintegration of the male nucleus, and perhaps subsequent arrest of further growth of the polar or egg nucleus, if it happens to visit the latter.

After the fertilization has taken place, the chromatic plasma coat which covers the egg-cell soon disappears, probably having been absorbed, and the lower end of the egg-cell also acquires a distinct cellulose membrane, which is clearly visible when the plasmolysis of the contents has occurred. Some starch grains are carried out from the synergid by the plasma flow, in which they are found spherical or ellipsoidal but not spindleshaped. This fact shows that the grains are undergoing some chemical change. The fate of these starch grains has not been followed, but it may be presumed that they become finally consumed. The remaining corpuscles in the synergid generally retain their original form and seem to remain unchanged, until they become absorbed together with the shrunk synergid when the fertilized egg begins to develop. The division of the primary endosperm nucleus quickly follows the fertilization, resulting in the migration of two daughter nuclei to both sides of the egg apparatus (Pl. VII, Fig. 10, end n.) when the division has succeeded twice. This nuclear position served as a clue to determine whether fertilization has taken place or not. As shown in Fig. Io and Text-fig. V, 8, generally the divided nucleus still possesses two nucleoli; such nuclear condition is retained through many nuclear generations (Text-fig. VI). The mitotic figures of the endosperm nuclei were often found in the preparations, but no favourable 
case to count the number of chromosomes has been observed. Once a nucleus in prophase of the second division was observed, in which fourteen chromatic filaments associated with two nucleoli were found (Text-fig. V, 9). This indicates the diploid nature of the endosperm nucleus. Renner (55) gave a good illustration of the nuclear plate found in the plasma sheet of the fertilized embryo sac in Oenothera biennis $\times$ Oe . Lamarckiana, in which-fourteen chromosomes are clearly delineated. This is the positive proof of a diploid nature of the endosperm nucleus. The first division of the fertilized egg nucleus occurs after several succeeding divisions of the primary endosperm nucleus; for instance, the egg nucleus remains unchanged, while sixteen endosperm nuclei are found in the plasma sheet.

An unusual case is shown in Text-fig. V, 10; in the upper right-hand side of the figure, a male nucleus $\left(m . n_{\cdot 1}\right)$ is shown just fusing with the egg nucleus $(e . n$.$) , and on the left-hand side the second nucleus \left(m . n_{._{2}}\right)$ is shown lying beneath the chromatic plasma mass, while the third $\left(m . n_{\cdot 3}\right)$ is just coming into contact with the large pole nucleus $(p \cdot n$.$) . No shadow of the$ vegetative nucleus could be found in the sac, of course, so that those just mentioned above must be three sperm nuclei. For explanation of such an aberrant case two alternatives are proposed. The first is that the presence of excess nuclei is brought about by intrusion of two sets of sperm nuclei due to the attack of two pollen-tubes on a single embryo sac, though the fourth nucleus does not happen to be found in the preparation. The second is that it is due to the production of some excess generative nuclei in the male gametophyte. Among the Angiosperms visit of two or more pollen-tubes on a single embryo sac sometimes happens, as stated by Shattuck (61) in Ulmus americana, by Juel (34) in Saxifraga granulata, by Němec (49) in Gagea lutea, by Compton (9) in Lychnis. Flos-cuculi, by Weinzieher (74) in Xyris indica, by Nawaschin and Finn (48) in Fuglans nigra and $\mathcal{F}$. regia, by Tchernoyarow (70) in Myosurus minimus, and as described above in Oenothera (P1. VII, Fig. 8), although in the latter case it was often quite difficult to determine whether they represent both ends of a ramified tube or belong to different stocks. Unfortunately in the preparation containing the aberrant figure in question the pollen-tube is lacking, in consequence of an accident while preparing, so that the specimen was not complete enough to afford a decisive conclusion. According to Weinzieher, two pollen-tubes pour out the contents into an embryo sac, but he does not mention anything about the further destiny of the poured contents. Nawaschin and Finn (48) report that two or three sets of male nuclei were often found ejected in a single embryo sac, but not two sperms fusing with an egg. The same was also observed by Tchernoyarow (70). The latter three authors' statements are illustrated by figures clearly delineated. Judging from the above-mentioned facts, especially the clear descriptions given by those three workers, it is reasonable to explain 
the fate of the extra male nucleus in the embryo sac of Oenothera by the first alternative proposed above, which was also maintained by Němec in the case of polyspermy in Gagea lutea.

The second alternative, that is, the production of an extra nucleus in the male gametophyte, may be no less applicable than the first one for the explanation of the case. Several examples referred to the latter case have been reported, one of which is that of Lilium aurantiacum examined by Chamberlain (7), who found three male nuclei in the pollen grain. Another is the production of four male nuclei in the pollen-tube of Ornithogalum and Scilla mutans, studied by Strasburger (65). No such cases have been found in Oenothera, but another aberrant case, which will be given below, suggests its probable occurrence. Therefore, though not conclusive, the writer is inclined to explain the case in question by the first as well as the second alternative, until some more conclusive facts are obtained.

Another aberrant case just mentioned is the fusion of an egg nucleus with two male nuclei, while the pole nucleus of the same embryo sac receives another male nucleus, as shown in Text-fig. V, II, I2. II shows that the egg nucleus is fusing with two male nuclei on both sides, and in 12 two nucleoli of different size are found in a large pole nucleus, which is therefore a perfect primary endosperm nucleus. The embryo sac from which these figures were drawn was carefully studied, and it was found that it had received only one pollen-tube. Thus it cannot be denied that an extra male nucleus was produced in the male gametophyte. Nermec (49) often observed triple fusion in the egg nucleus in Gagea litea, and proposed several hypotheses for this question, suggesting the origin of a plant possessing triploid nuclei as having been derived from an egg nucleus fertilized by two male nuclei. Though there is some difficulty in arriving at a satisfactory conclusion as to the distribution of the chromosomes at the time of the reduction division in the next generation, the origin of the triploid mutant must be ascribed to a fusion of diploid and haploid germ nuclei, in order to be more rational within the scope of the present knowledge. In this respect, Němec's view seems to be very ingenious, who substituted two male nuclei for the diploid germ nucleus. Some would be opposed to his view, advocating that the dispermic egg cannot give rise to a new plant owing to the early disintegration. But our present knowledge does not permit us to state whether the dispermic egg can develop further or not, and consequently we can neither deny nor affirm it. The opponent must be influenced by some zoological evidence, for an actual development of the dispermic egg-cell has been recorded by several investigators, though some irregularities in the distribution of the chromosomes in further cell division. may occur, being often induced by interference of the extra centrosomes. But in the higher plants no such interference does occur even if polyspermy may happen. At any rate, Němec's view seems to be the most natural one among several 
hypotheses as yet proposed. Really, triploid mutants in Oenothera were reported by Lutz $(38)$, Stomps $(63,64)$, and Gates $(19 a)$. The first-named observer, having found them in the offspring of Oenothera lata $\times O e$. Lamarckiana and self-pollinated Oe. lata, attributed the origin of such mutants to the union of the reduced male nucleus and unreduced egg nucleus. Stomps independently published the occurrence of a similar phenomenon in Oe. Lamarckiana, which he named semigigas, and he got also a triploid offspring from Oenothera biennis and named it Oenothera biennis semigigas. Though these first two investigators did not touch the dispermic problem, the case would be easily and smoothly explained by Nèmec's hypothesis, which has, however, been suggested by Gates as being less probable than the union of diploid and haploid sex nuclei. ${ }^{1}$

After the ejection of the contents, the opening at the tip of the pollentube is closed by some mucilaginous substance (Pl. VII, Fig. 8 ; Textfig. VII, I, 3, m.s.) forming the residue (r.s.) of the contents of the tube. If there remain any starch grains they gradually disappear, and the contents finally become filled with many globular liquid drops as shown in Textfig. VII, 2, r.s. The filiform apparatus persists for a long time, even when the rest of the synergids is entirely absorbed at the time of embryo formation.

\section{Cell Walls of Egg Apparatus.}

For the determination of the chemical character of the cell walls of the egg apparatus, a great many microtome sections have been treated with different stains and reagents, and the results obtained are as follows :

Filiform apparatus. The filiform apparatus (Text-fig. VII, I and $3, f i l$.) was stained red with aqueous solution of Congo red; also it was coloured purplish blue with chlorzinc-iodine. A treatment with freshly made cuprammonia gave the following result. Sections were allowed to stand in this reagent for half a day to 30 hours; the apparatus was then found entirely dissolved, as shown in Text-fig. VII, 4 , $a p$., often leaving some cloudy residue.

1 After the manuscript was finished, Dr. I. Ôsawa published an interesting account of triploid mutants in the garden races of Morus in the Bulletin of the Imperial Sericultural Experiment Station, Japan, vol. i, No. 4, 1916 (Japanese). According to this investigator, in forty-two garden races of Morus examined by him, supposed to have been derived from Morus hombycis, M. alba, M. indica, and $M$. multicaulis(?), each of thirty-two races possesses fourteen haploid and twenty-eight diploid chromosomes. And a certain one of the fourteen haploid chromosomes is very conspicuous for its remarkable size. On the other hand, in the remaining ten races he studied, forty-two chromosomes are equally found in the vegetative cell, three of which are always markedly larger than the others. As he did not find such a race that has twenty-eight haploid chromosomes, he is inclined to believe that those ten races just mentioned have not been derived from a hybrid between two kinds of races which possess fourteen and twenty-eight chromosomes respectively, but really descended from a triploid mutant. Although the investigator adopts the prevailing hypothesis, i. e. the union of the haploid and diploid generative cells for the explanation of the origin of those triploid mutants, the case will be smoothly explained by Němec's hypothesis. The triploid mutants in question are all sterile, as Dr. Ôsawa stated, but having been propagated vegetatively, for instance by grafting, so many triploid mutants seem to have been preserved and protected from extinction. 


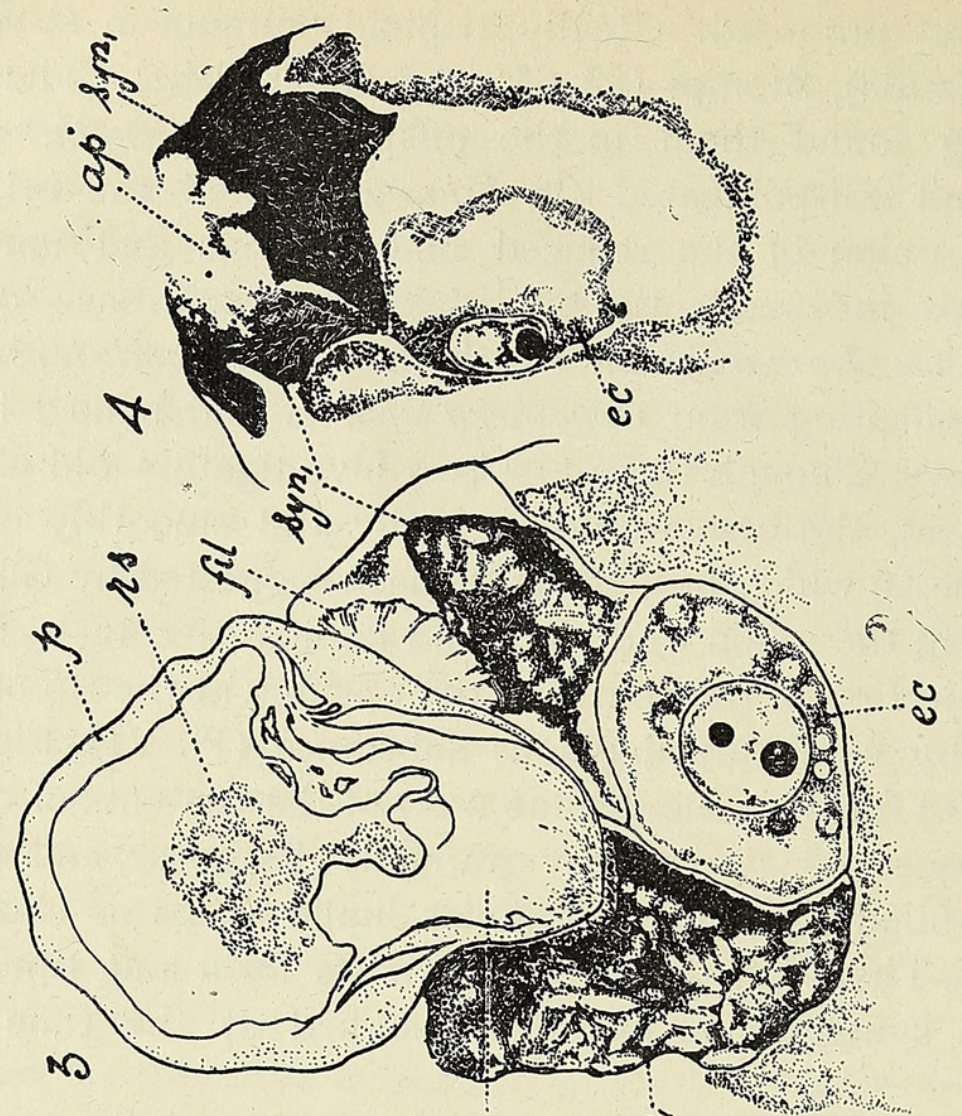

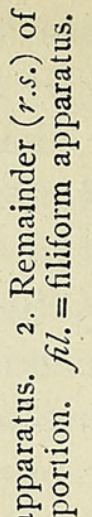

«ँ:

$\stackrel{\overbrace{}}{\stackrel{5}{\Xi}}$

इष $x$

\&

สี

कृ $x$

कू है त

를

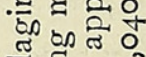

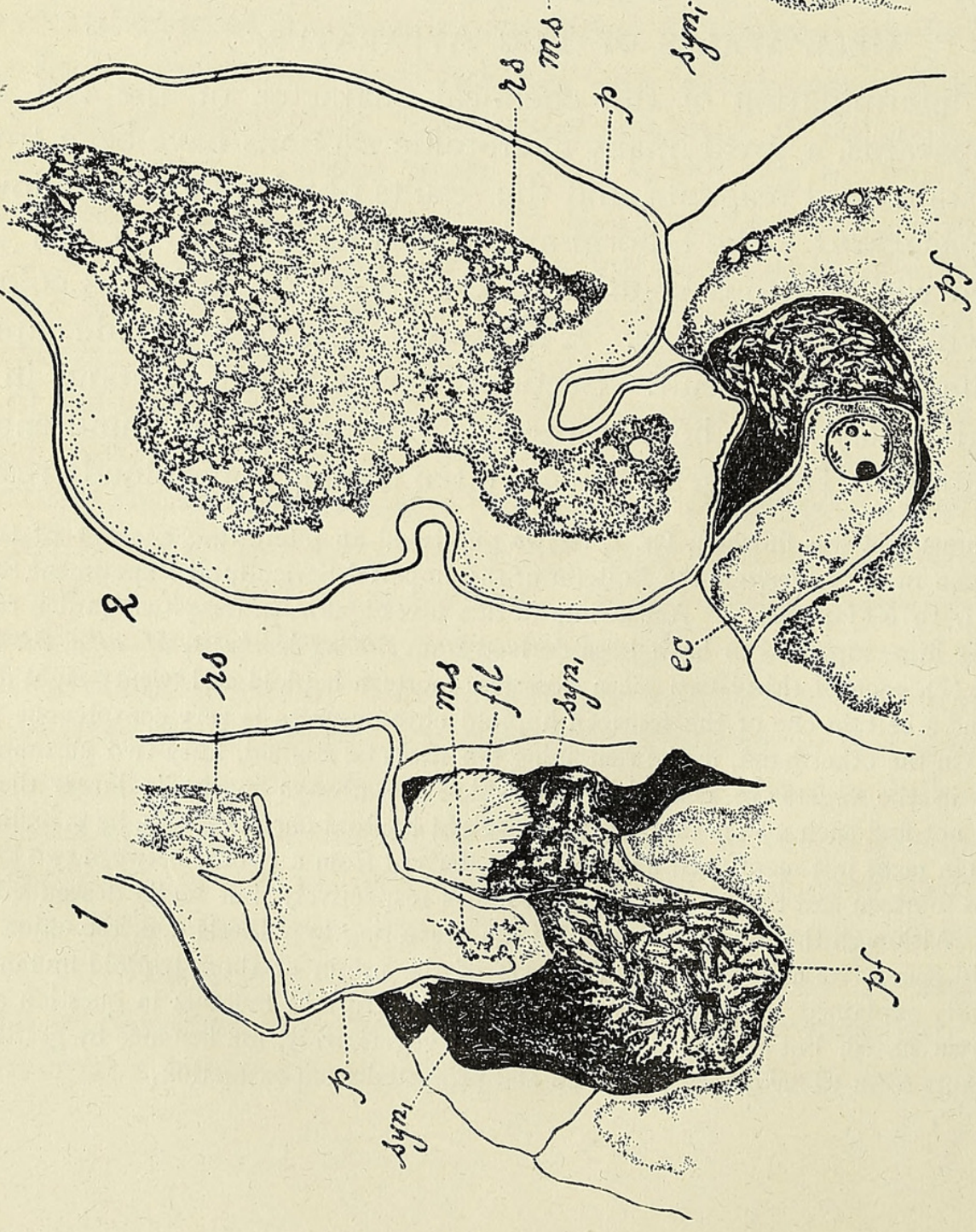

चี हैं

ज政

हैं山

ग्ड

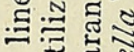

บำ

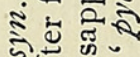

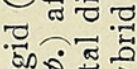

记苟

ถ⿻ำ

플

i⿺辶大

… हू

要政

宅

的苛

노옹

ฮี

ฮี 웛

Оิ.

궁

मी के है

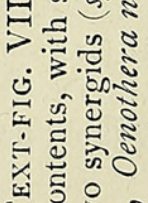

된

近 
These reactions show that the filiform apparatus is of cellulose. Then, aqueous solution of ruthenium red was tried; the apparatus often remained entirely unstained, but sometimes it stained a pale pink or even a bright pink. This reaction indicates the occasional presence of pectic substance, which is against Habermann's result (25), i. e. he denies the association of this substance in the filiform apparatus.

Synergid and egg-cell. The cell wall of the synergid showed a cellulose reaction with Congo red and chlorzinc-iodide, and sometimes coexistence of pectic substance was clearly demonstrated by ruthenium red or methylene blue. As already stated, the distinct wall is differentiated around the upper two-thirds of the mature oosphere, though the remaining naked free end acquires the wall shortly after fertilization. The chemical nature of the wall is quite identical with that of the synergid. The lower naked end of the oosphere, as stated above, must be enclosed by the plasma membrane, which gave quite indifferent reactions to those reagents.

Wall of pollen-tube. The apical portion of the pollen-tube, which was in contact with the egg apparatus, was carefully studied. The wall stained with Congo red, and a bright pink was obtained with ruthenium red or sky blue with methylene blue. These colouring reactions show the coexistence of cellulose and pectic substance. Removal of cellulose with cuprammonia was easily done, and the residual substance fully gave the pectic reaction; but the removal of pectic substance by a weak base after the treatment with a weak solution of hydrochloric acid was entirely unsuccessful; moreover, the boiling method for the latter purpose was found quite inapplicable to the delicate section. It was often the case that, after the contents had been ejected, the wall of the apical portion of the pollen-tube was lined with some peculiar substance (Pl. VII, Figs. 8, I2, m.s.; Text-fig. VII, I, 3, m.s.), which did not show any special colour reactions with Congo red or ruthenium red. As callose is commonly found in the upper part of the tube as the main component of the septa, treatments with corallin-soda, aniline blue, or sodium carbonate were applied to the substance in question, but it gave no callose reactions. For the control, leaves of Ficus containing cystoliths, stem of Benincasa and Cucumis for the callus on the sieve-plates, and pollen-tubes of Thea japonica possessing callose septa were fixed and treated in the same way. The callose thus treated showed the same reaction as that in the fresh condition. Thus the nature of the lining substance under discussion was left undetermined, except that, judging from the position and general appearance, it may be a kind of mucilaginous substance which seals the opening and lines the apical wall.

Self-Sterile Hybrid Between OE. NUTANS AND OE. PyCNOCARPA.

There were two forms of the hybrids between Oenothera mutans and Oe.pycnocarpa, when the materials were collected. One of the hybrids, 
which was named pycnella by Atkinson, had flowers like those of Oe. pycnocarpa and was very liable to the attack of a kind of Peronospora, which was always parasitic only on Oe. pycnocarpa. This one he called a segregated hybrid, because it developed to the full expression of certain characters selected from each parent. The other, which had petals like those of Oe. mutans or somewhat modified by the other parent, he called mutanella. This was a blend, since the characters were taken from each parent, and an intermediate character of most members appeared in the hybrid. Pycnella was quite fertile; its pollen valid for both parents as well as for mutanella, pycnella, and itself; while mutanella was self-sterile, though its pollen or eggs were perfectly good when combined with those of the parent, all other hybrids, and even Oe. Lamarckiana. Some experiments for this self-sterility were undertaken, though it was merely preliminary. The result is that the pollen grains easily germinate, and the pollentubes actively penetrate the stigmatic tissues, when the self-pollination is carried on in mutanella. The inner morphological aspects of the gametophytes are quite normal, but the growth of the tube is so sluggish that they cannot enter the stylar tissues even in three days after pollination, when the ovules show the sign of disintegration. On the other hand, in the normal case the pollen-tube gets at the embryo sac in fifty hours; generally the ovules of Oenothera begin to disorganize in three days after the flowing if not visited by the pollen-tubes, and in such a case some of the embryo sacs at times show a sign of disintegration in sixty-eight hours after blooming.

It is interesting to notice that in the hybrids, as in many cases, self-sterility is produced owing to the fact that the tube does not grow quickly enough to reach the ovule in time for fertilization. As to the cause of the feeble growth of the tube we scarcely know any explanation better than Jost's well-known hypothesis (33), namely, 'Möglich wäre auch, dass auf den Reiz des Pollenschlauches hin nicht Nährstoffe, sondern andere Stoffe im Leitgewebe sezerniert würden. Die Reaktion müsste auf fremden Pollen eintreten, und ihr Erfolg bestände in der Sekretion wachstumsreizender Stoffe.' It is also stated by Compton (10) that: 'If we compare pollination with fungal or bacterial infection it might be expected that the result would be the formation of antibodies.' 'If there be an analogy between fertilization and infection, there is also one between sterility and immunity. There seems to be two main methods by which immunity is attained. In one the host is constitutionally resistant to the attacks of the parasite, this being the more frequent method. In the other the host is over-susceptible, and the attack of the parasite produces a quantity of decomposing matter which inhibits its further growth. Both these methods are paralleled in cases of failure of fertilization.' 
s

3. in

$\cdot(0)=0$

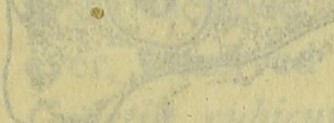

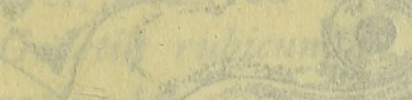

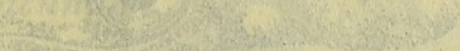

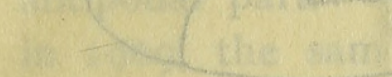

3

$\left\{\begin{array}{l}3 \\ -3\end{array}\right.$

ristis

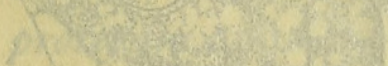

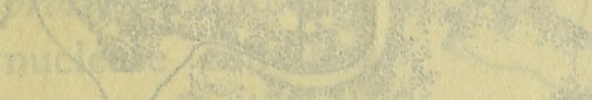

$(1-1) \times(3+2)=$

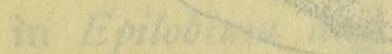

generd of the Oran
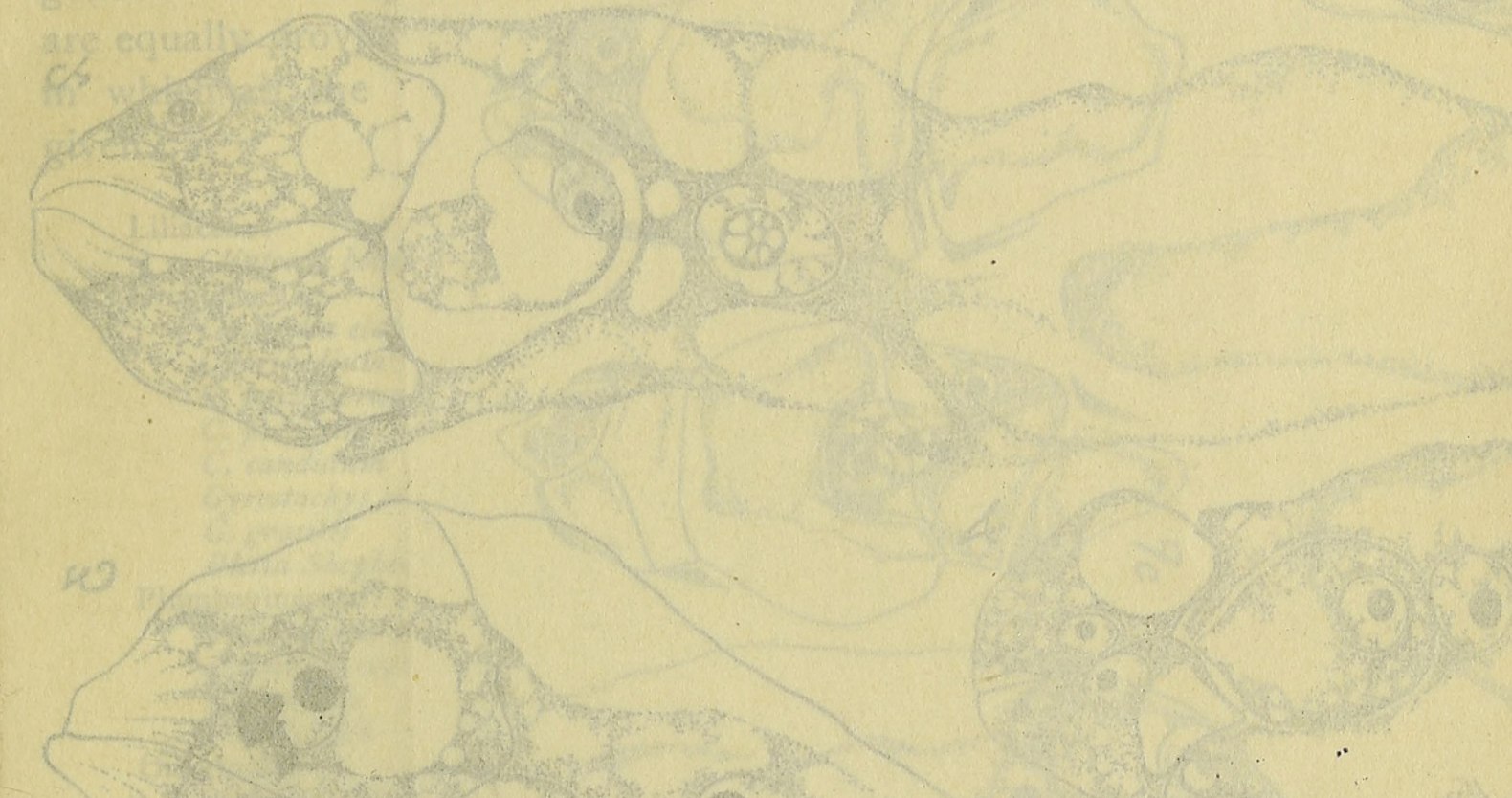

(n)

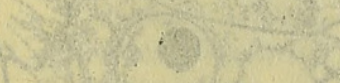

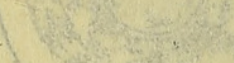

$x^{2+2}+50$

(6)

(1)

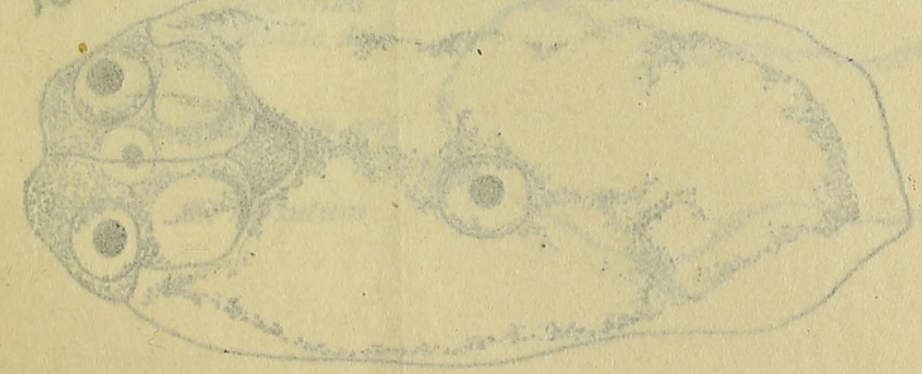

c

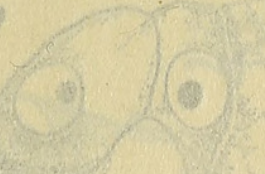

(5) 

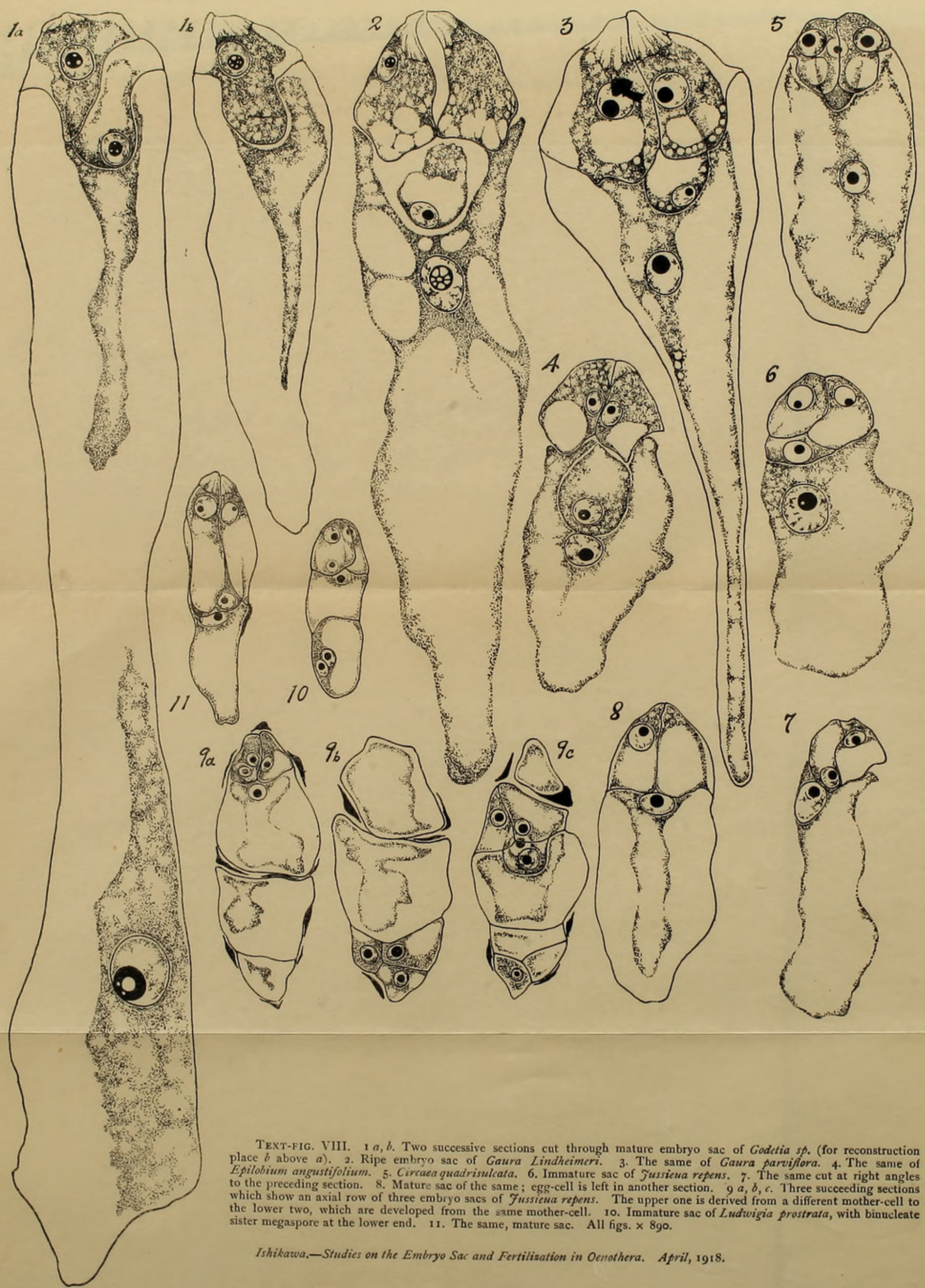

TEXT-FIG. VIII. I $a, b$. Two successive sections cut through mature embryo sac of Godetia sp. (for reconstruction place $b$ above $a$ ). 2. Ripe embryo sac of Gaura Lindheimeri. 3. The same of Gaura parviflora. 4. The same of Epilobium angustifolium. 5. Circaea quadrisulcata. 6. Immature sac of Jussieua repens. 7. The same cut at right angles to the preceding section. 8. Mature sac of the same; egg-cell is left in another section. $9 a, b, c$. Three succeeding sections which show an axial row of three embryo sacs of Fussicua repens. The upper one is derived from a different mother-cell to the lower two, which are developed from the same mother-cell. 10. Immature sac of Ludwigia prostrata, with binucleate sister megaspore at the lower end. 11. The same, mature sac. All figs. $\times 890$. 



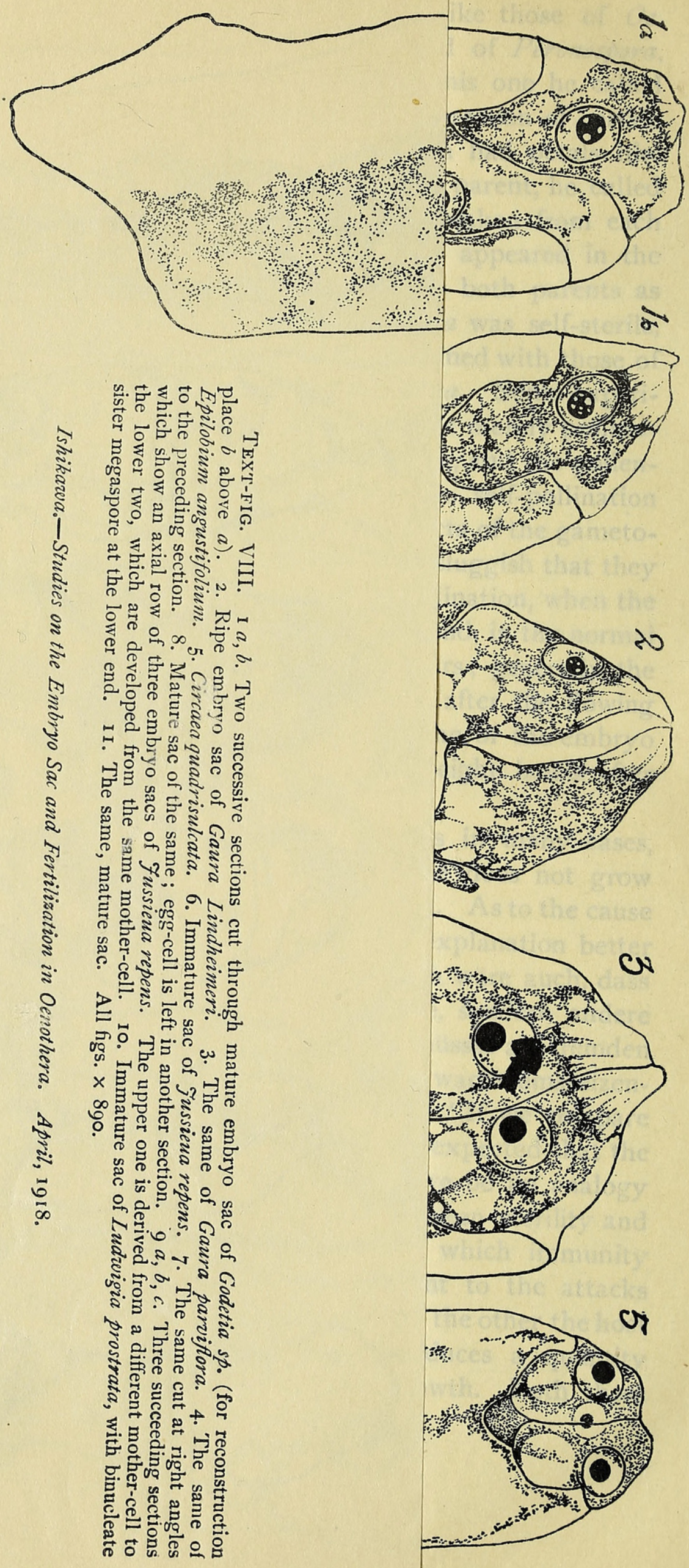




\section{Tetranucleate Embryo Sac.}

In 1900 Chodat and Bernard (8), applying recent cytological methods, first described a tetranucleate embryo sac. This phenomenon was, however, observed by Hofmeister already in 1847 (26) and 1849 (27) in Godetia rubicunda, though he did not pay any special attention to the antipodal part. Geerts (21) and Modilewski (42) were the next to record, in 1909, the same cases as occurring in some plants belonging to the Onagraceae. Since then, several investigators have added some more examples to the list of such aberrant cases.

While working on Oenothera, the present writer also examined embryo sacs of Gaura Lindheimeri, G. parviflora, Fussieua repens, Ludrwigia prostrata, and Circaea quadrisulcata for comparison, and found that the tetranucleate condition is of usual occurrence in these plants (Text-fig. VII, I-I2). Besides, the same has also been ascertained in Godetia sp. and in Epilobium angustifolium. Thus, the representatives of the principal genera of the Onagraceae examined, so far as the embryo sacs are concerned, are equally provided with four nuclei, as may be seen in the following table, in which all the recorded plants having tetranucleate embryo sac are given :

Liliaceae :

Clintonia borealis

Orchidaceae :

Gastrodia elata

Cypripedium spectabile

C. parviflorum

C. pubescens

C. candidum

Gyrostachys cernua (not always, but in some ovules) G. gracilis Bletia Shepherdi

Plumbaginaceae :

Plumbagella micrantha

Plumbago zeylanica

$P$. capensis

$P$. pulchella

Onagraceae :

Lopezia coronata

Boisduvalia densiflora

Clarkia sp.

C. elegans

C. pulchella

Fuchsia sp.

$F$. procumbens

F. coccinea

F. pumila

$F$. fulgens

F. 'Marinka'

F. 'Émile de Wildeman', etc.

Epilobium angustifolium

By Smith

1910

Kusano

Pace

,

"

,

Sharp

" " $"$

",

Dahlgren

; ,

",

Täckholm

1915

1908

",

"

I9I 4

I 9 I 2

E. hirsulum

werner

Täckholm

Werner

Täckholm

1915

"

"

$\begin{array}{cc}", & ", \\ , " & ", \\ \text { Modilewski } & \text { 1909 } \\ \text { Werner } & 1914 \\ \text { Täckholm } & 1915 \\ \text { Ishikawa } & , " \\ \text { Täckholm } & , "\end{array}$




\begin{tabular}{|c|c|c|}
\hline E. Doaonaei & Modilewski & 1909 \\
\hline Circaea Lutetiana & $\{$ Werner & IOI4 \\
\hline C. quadrisulcata & $\begin{array}{l}\text { Ishikawa } \\
\text { Modilewski }\end{array}$ & $\begin{array}{l}1915 \\
1909\end{array}$ \\
\hline Oenothera biennis & $\left\{\begin{array}{l}\text { Werner } \\
\text { Renner }\end{array}\right.$ & I914 \\
\hline Oe. Lamarckiana & $\left\{\begin{array}{l}\text { Geerts } \\
\text { Werner }\end{array}\right.$ & $\begin{array}{l}1909 \\
1914\end{array}$ \\
\hline $\begin{array}{l}\text { Oe. rhizocarpa } \\
\text { Oe. tetraptera } \\
\text { Oe. coccinea }\end{array}$ & ", & $"$ \\
\hline Oe. nutans & Ishikawa & I9"5 \\
\hline Oe. pycnocarpa & $"$ & $"$ \\
\hline G. gloriosa & Täckholm & $"$ \\
\hline G. Whitneyi & $"$ & $"$ \\
\hline $\begin{array}{l}\text { G. amoena } \\
\text { Gaura Lindheimeri }\end{array}$ & Ishikawa & 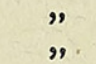 \\
\hline G. parviflora & $"$ & $"$ \\
\hline Ludwigia prostrata & $"$ & $"$ \\
\hline $\begin{array}{l}\text { Fussieua repens } \\
\text { F. villosa }\end{array}$ & Täckholm & $"$ \\
\hline $\begin{array}{l}\text { F. suffruticosa } \\
\text { Podostemaceae : }\end{array}$ & " & $"$ \\
\hline Podostemon subulatus & Magnus & 1913 \\
\hline $\begin{array}{l}\text { Hydrobium olivaceum } \\
\text { farmeria metzerioides }\end{array}$ & $"$ & $"$ \\
\hline $\begin{array}{l}\text { Farmeria metzgerioides } \\
\text { Balanophoraceae: }\end{array}$ & " & $"$ \\
\hline $\begin{array}{l}\text { Helosis guayanensis } \\
\text { Euphorbiaceae: }\end{array}$ & Chodat et Bernard & 1900 \\
\hline Codiaeum sp. & Arnoldi & I9I 2 \\
\hline $\begin{array}{l}\text { Ceramanthus sp. } \\
\text { Urticaceae: }\end{array}$ & $"$ & $"$ \\
\hline Elastostemma acuminatum (in some cases) & Strasburger & 1910 \\
\hline
\end{tabular}

Thus, it may not be unreasonable to assume that all the genera of the Onograceae are provided with a tetranucleate embryo sac except one deviated genus, Trapa, which has been reported by Gibelli and Ferreo (2*), working on Trapa natans, as having a normal 8-nucleate embryo sac. According to those investigators the embryo sac of Trapa natans directly develops from a mother-cell just as in the case in Lilium. As their paper was published so long ago as $\mathrm{I} 89 \mathrm{I}$, these results require a re-investigation, and it is much to be desired to undertake it inasmuch as the present genus has been put into different families by different authors. ${ }^{1}$

It was therefore thought advisable to examine Trapa natans and its var. incisa. Although the material was not quite sufficient for tracing whole developmental stages, yet two essential points were clearly made out. The embryo sac mother-cell forms a tetrad due to the reduction division as shown in Text-fig. IX, 2, 3, and the chalazal megaspore develops the embryo sac $(3,4)$. The mature embryo sac is very slender, slightly recurved, tapering upwards, and provided with a normal egg

1 For instance, in Onagraceae by Bentham and Hooker; treated as an appendix to the Onagraceae by Eichler; included in Hydrocaryaceae by Raiman in Engler's Pflanzenfamilien; reunited into Oenotheraceae by Engler in Syll. der Pflanzenfam. (ed. 8); and treated even as an isolated member of Halorrhagidaceae by Endlicher, Lindley, Parmentier (54), \&c. 

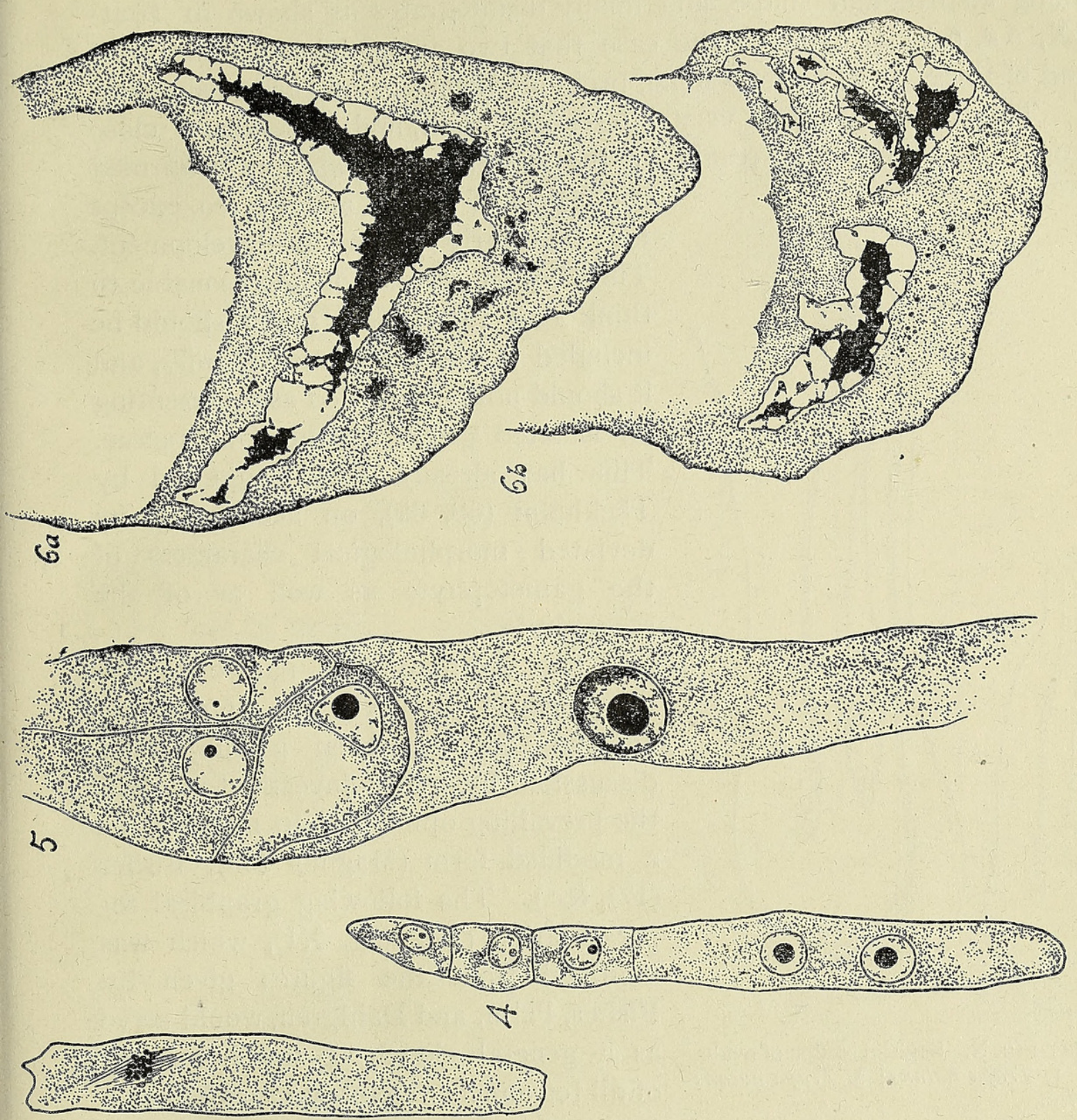

Q

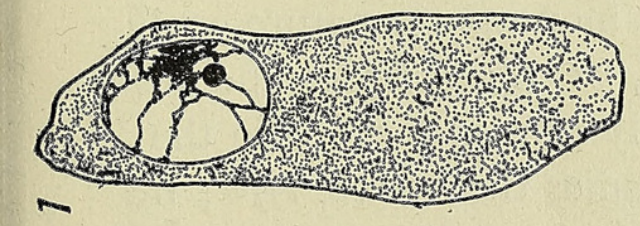

芯势

密密

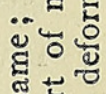

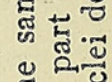

跑苛

त菅究

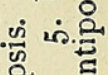

胥.

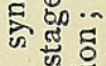

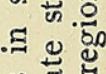

๘ँ

远

듬.

ㅍ. 드

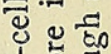

ปे

ज्०

छี

㻤

을

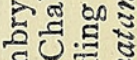

되

+ o

of कै

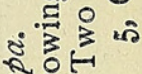

50.

40

$0 x$

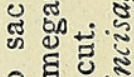

을

है

되늘

范芯号

०स है है

的命

国.

量要 
apparatus, secondary pole nucleus as well as antipodal nuclear group being present (Text-fig. IX, 5 and $\mathrm{I}, 2$ ). The antipodals always acquire no separating walls, and sooner or later each nucleus becomes chromatic, assuming an irregular shape, and finally disintegrates as shown in Textfig. IX, $6 a, 6 b$. It is often the case that two antipodal nuclei do exist instead of three, or sometimes none, probably owing to an early disintegration. This is no doubt a very interesting point, and deserves a close investigation. Thus, the result of the writer's investigation confirmed

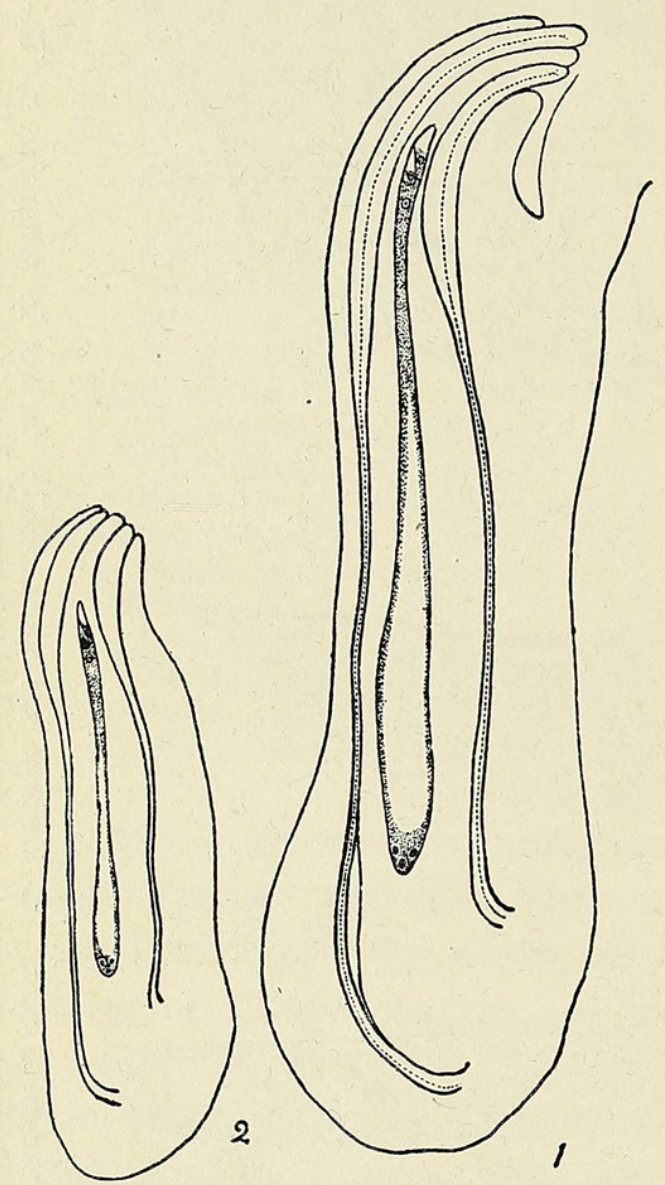

TeXt-fig. X. Sagittal section of ovule. $\times$ 30. I. Trapa natans; 2. Trapa natans var. incisa.

As shown in the diagram, the embryo sacs of the Onagraceae, of Codiaeum, of Gastrodia, and of Clintonia are of a monosporic nature, and those of Dicraea, of Cypripedium, of Podostemon, of Hydrobium, and of Helosis are bisporic, while in Plumbagella it is really tetrasporic. If in the latter case the nuclei divide once more, the sac assumes the Lilium type; if they divide twice, the sac acquires the type which comprises all known cases of the 16 -nucleate embryo sacs.

Nearly all the tetranucleate embryo sacs do not possess antipodals, but contain a single polar in each of them. As stated above, the axis of the spindles at the second division of the nucleus of the embryo sac cell are as 

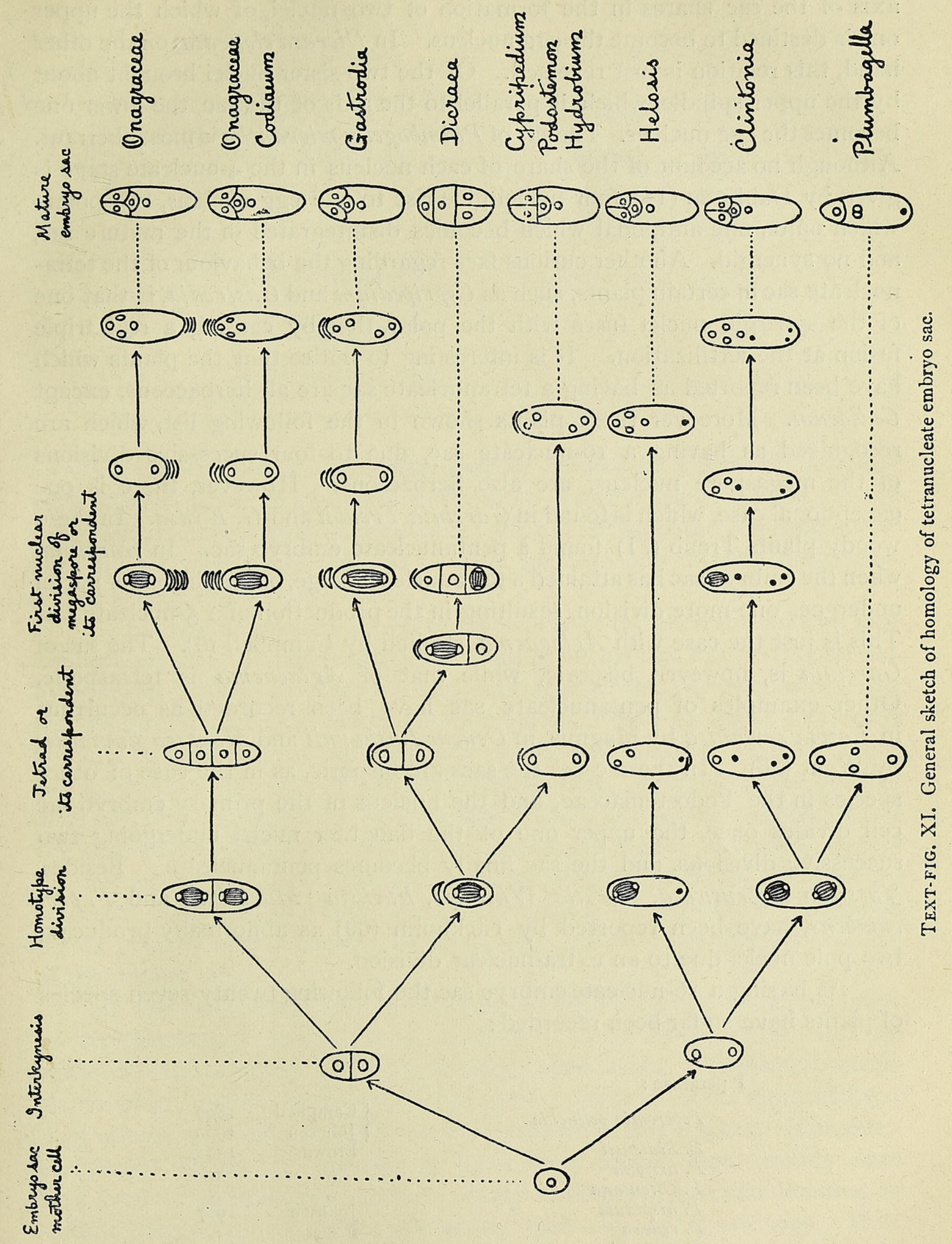
a rule perpendicular to each other, and the one which is parallel to the main axis of the sac shares in the formation of two nuclei, of which the upper one is destined to become the egg nucleus. In Dicraea elongata, on the other hand, this relation is just reversed. Of the two sister nuclei brought about by the upper spindle, which is parallel to the axis of the sac, the lower one becomes the egg nucleus. The sac of Plumbagella micrantha is most aberrant. Although no account of the share of each nucleus in the 4-nucleate stage is given by Dahlgren (14), four nuclei give rise to one egg nucleus, two polars which unite, one antipodal which becomes disintegrated in the mature sac, and no synergid. Another curious fact regarding the behaviour of the tetranucleate sac in certain plants, such as Cypripedium and Gastrodia, is that one of the synergid nuclei fuses with the polar, thereby causing a real triple fusion at the fertilization. It is interesting to notice that the plants which have been reported as having a tetranucleate sac are all herbaceous, except Codiaeum. Moreover those plants shown in the following list, which are recognized as having a I6-nucleate sac, due to four successive divisions of the megaspore nucleus, are also herbaceous. However, there is one exceptional case, which is found in Garcinia Treubii and G. Kydia. In these woody plants Treub (71) found a pentanucleate embryo sac. In Garcinia, when the embryo sac has attained a tetranucleate stage, one of the upper nuclei undergoes one more division, resulting in the production of a 5 -nucleate sac. This is just the case with Aglaonema, studied by Campbell (6). The sac of Garcinia is, however, bisporic, while that of Aglaonema is tetrasporic. Other examples of pentanucleate sac have been recorded as occurring in Lazvia zeylanica by Magnus, in Oenone Imthurnii and Mourera fuviatilis by Went (76). In these cases the sacs are bisporic, as in the case of other species in the Podostemaceae, and the nucleus of the primary embryo sac cell divides once, the upper one of the daughter nuclei undergoing two successive divisions, and the sac finally becomes pentanucleate. Besides, Fussiena suffruticosa, Godetia Whitneyi, Fuchsia 'Marinka', and F.procumbens, have been reported by Täckholm (69) as abnormally producing two pole nuclei due to an extra-nuclear division.

As having a I6-nucleate embryo sac the following twenty-seven species of plants have so far been recorded:

Piperaceae :

Peperomia pellucida
P. Sintensii
$P$. arifolia
$P$. Ottoniana
$P$. hispidula
$P$. reflexa
$P$. verticillata
$P$. scandens
$P$. metallica
$P$. Fraseri var. resedaeflora

$\begin{array}{cc}\begin{array}{cc}\text { Campbell } \\ \text { Johnson }\end{array} & 1899 \\ \text { Brown } & 1900 \\ \text { I908 }\end{array}$




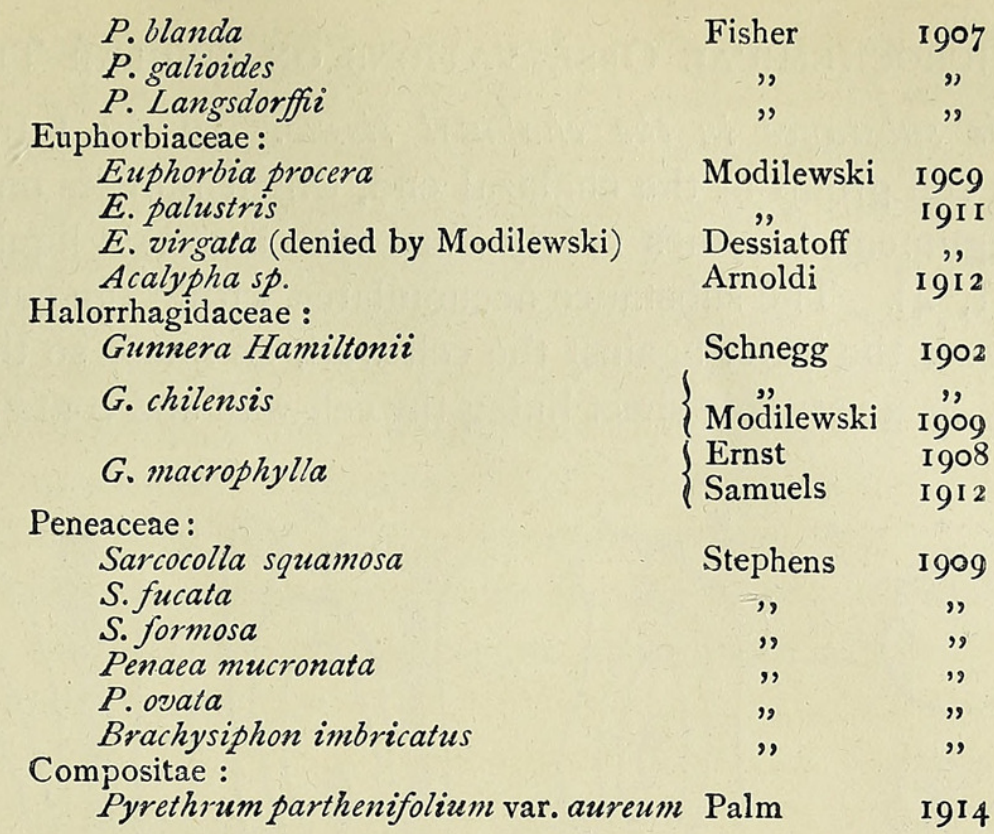

The embryo sac of Tanacetum vulgare studied by Palm (53) is somewhat aberrant from the 16 -nucleate condition. The nucleus of the embryo sac cell, which is monosporic, divides twice; the upper two of the resulting nuclei also divide twice, while the rest of them undergo one division only, thus a Io-nucleate embryo sac results.

As already mentioned above, those owners of the aberrant embryo sacs are herbaceous. An interesting case relating to this fact has been observed by Johnson (32) and Fischer (17), who state that all the Peperomias hitherto studied are herbaceous, while another genus, Piper, so far as examined is found to have a 8 -nucleate sac, and is a woody climber. On the other hand, Modilewski $(43,44)$ and Lyon state that, among fourteen species of Euphorbia examined, E. procera and E. palustris are I6-nucleate, while the rest possess a normal sac. Such an aberrant case of embryo sac is scarcely known to occur in the woody plants already studied of the Euphorbiaceae. Generally speaking, in the same genus or family, only herbaceous plants possess I6- or 4-nucleate sacs, while woody members have a sac of the normal type.

At any rate, tetra- and I6-nucleate embryo sacs are to be regarded as representing a derived type, probably caused by mutation and by variation, in a certain stage of phylogenetic development. Those herbaceous plants which possess such a modified gametophyte must be more evolved than others, especially than the woody members in this respect. Moreover, herbaceous plants are believed to have been derived from woody ones by a gradual decrease in amount of woody elements of vascular bundles, as held in Jeffrey's school, principally basing upon anatomical evidence. Thus the view regarding herbaceous plants as derivatives is supported by both the gametophytic and sporophytic characters. 


\section{Some Microchemical Observations on Ovular Tissues.}

Chromatic substance in the chalazal tissue. In the tetrad stage of mother-cell, a cell group at the chalazal end, which borders on the base of the inner integument, becomes nearly filled with a certain liquid substance (Text-fig. XII, 4). The substance accumulates within the cytoplasm, and gradually presses the latter against the cell-wall, so much so that the cytoplasm is found as a very thin sheet lining the cell-wall and containing a much
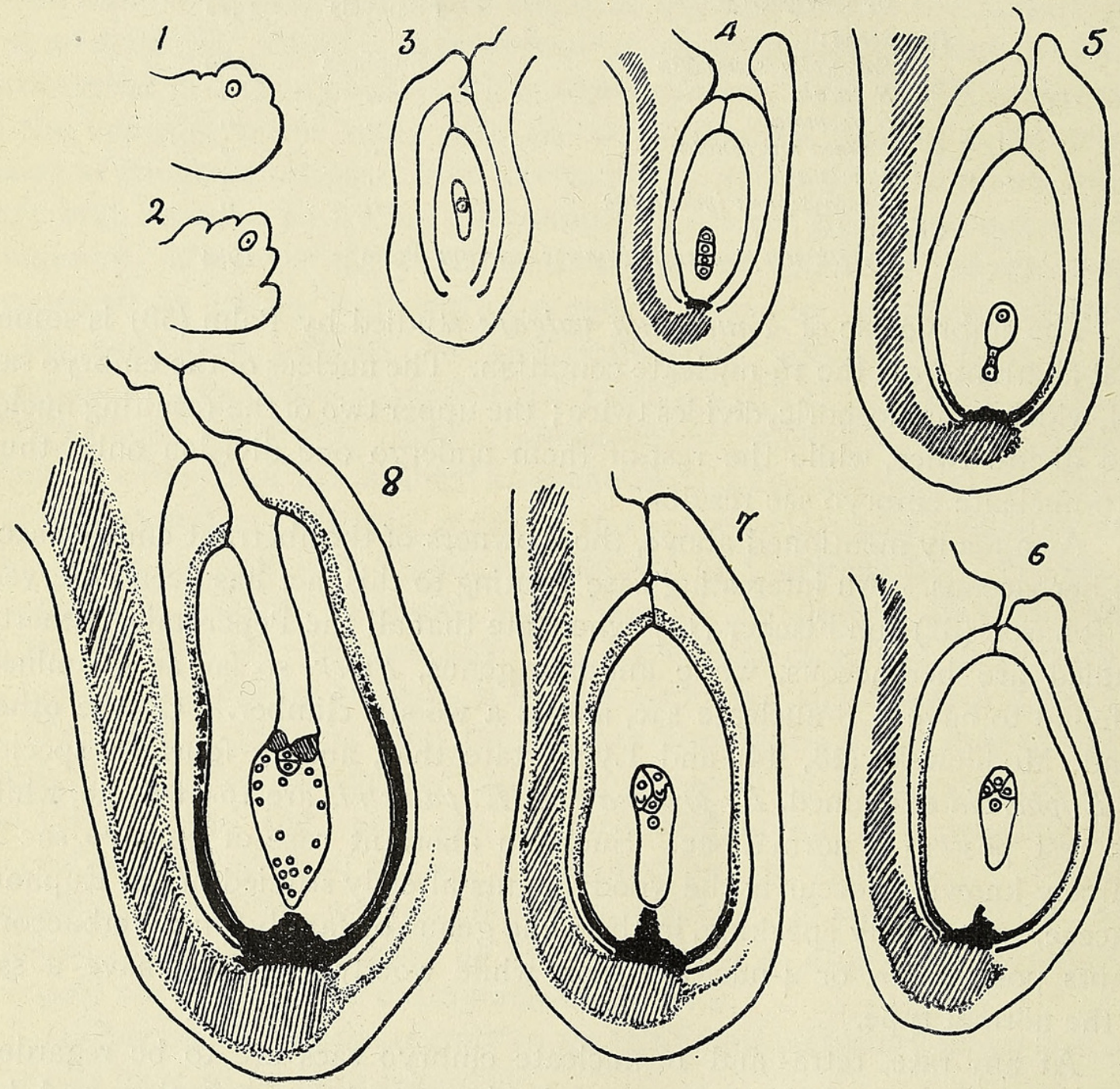

TEXT-FIG. XII. Various stages showing distribution of chromatic substance with reference to development of ovule. Hatched part, conducting passage ; darkly shaded part, tissues impregnated with chromatic substance of the first kind; dotted part, those containing substance of the second and third kind. All figs. $\times$ I 40 .

compressed nucleus (Text-fig. XIII). In an advanced stage (Text-fig. XII, 5), the substance in question prevails in the chalazal cells which are situated above the end of the conducting passage, and spreads in all directions, occupying the main part of the contents of the neighbouring tissues (Text-fig. XII, 6, 7). Finally the tissue lying between the conducting passage and the embryo sac, and the basal half of the inner layer of the inner integument, 
become impregnated with the substance (Text-fig. XII, 8), which is coloured black with Flemming's fluid or beautifully stained with safranin, malachite green, and iron-alum-haematoxylin in the fixed material. According to Werner (73) those cells which contain the chromatic substance are destitute of nucleus due to gradual disintegration. In the material examined by the writer, however, they possess sound nuclei (Text-fig. XIII) even at the time of endosperm formation; they are very easily seen if treated with yellow prussiate and chloride of iron. Before the first appearance of such impregnation, liquid substance of another kind, which is stained with light green in the fixed material and gives a tannin reaction with chloride of iron in the fresh condition, appears in the lowermost cells of the inner integument and in those of the neighbouring region at the terminal end of the conducting tissue (Text-fig. XII, 4).

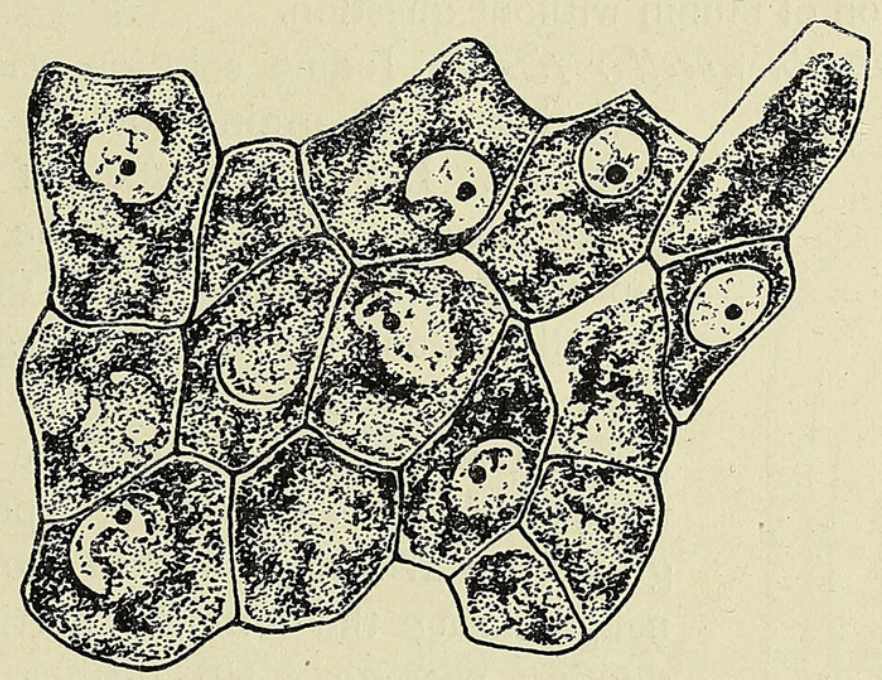

TEXT-FIG. XIII. Portion of chalazal tissue containing chromatic substance. $\times 900$.

Then it spreads to the inner cell layer of the inner integument, but sooner or later it becomes replaced by the one first mentioned, perhaps owing to a chemical change, except that in the upper half of the integument, which remains unchanged. Moreover, in a mature ovule a cylindrical layer of cells surrounding the conducting passage and a sheet of cells in the basal part of the outer integument are also filled with granular substance, which, in the fixed material, stains also with light green. Though this chromatic substance of the third kind at least may contain tannic substance, the chemical nature is left undecided, for the test tried was found unsuccessful to determine it. As the cells which contain any of those three kinds of the chromatic substance stain light black colour with Sudan III in the fixed material, it was found advisable to study the ovules in fresh condition. But having no material of Oe. mutans or Oe. pycnocarpa at hand, Oe. biennis var. canescens and Oe. odorata were used, which are nearly the same as far as the internal structure are concerned. The result is as follows : 


\begin{tabular}{lcc}
\multicolumn{1}{c}{ Reagent. } & $\begin{array}{c}\text { Chromatic substance of the } \\
\text { first kind accumulated in } \\
\text { the chalazal region. }\end{array}$ & $\begin{array}{c}\text { Chromatic substance } \\
\text { of the second } \\
\text { kind. }\end{array}$ \\
$\begin{array}{l}\text { a-naphthol }+\mathrm{H}_{2} \mathrm{SO}_{4} \\
\text { Sudan III }\end{array}$ & black & black \\
Osmic acid & black & $\begin{array}{l}\text { black } \\
\text { Millon's reagent }\end{array}$ \\
$\begin{array}{l}\text { Eosin } \\
\mathrm{FeCl}_{3}\end{array}$ & slightly stainable \\
$\mathrm{HNO}_{3}$ & black \\
$\mathrm{NaOH}^{2}$ after $\mathrm{HNO}_{3}$ & brownish yellow & \\
Iodine & blow \\
Alcohol & insoluble & soluble \\
Ether & soluble &
\end{tabular}

Judging from the results tabulated above, the substance of the first kind in question must be some ultimate substance which does not share in the nutritive process, while the second kind of the substance under discussion is really a solution of tannin without question.

Starch grains in mucellar tissue. Iodine solution was employed for detecting starch grains both in fixed and fresh

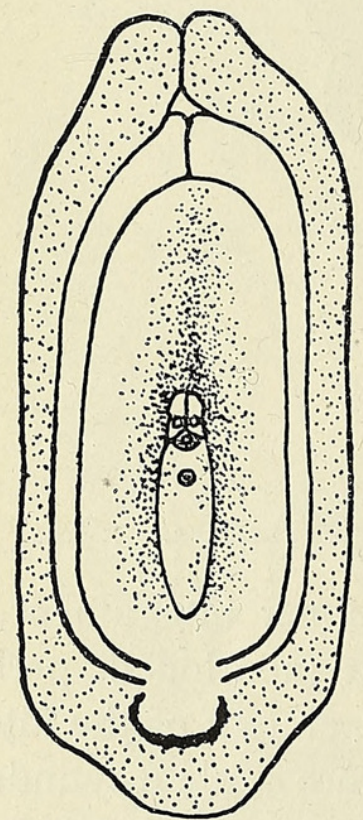

TexT-FIG. XIV. Longitudinal section of ovule showing distribution of starch grains by means of dots. materials. In the tetrad stage of the mother-cell, starch grains accumulate in the nucellar tissue, especially densely surrounding the gametophyte as well as along the future passage of the pollentube, where they are found in large granules; perhaps some of them become glucose in due time, which serves to attract the pollen-tube. The grains are also deposited in the chalazal tissue neighbouring the terminal portion of the conducting passage. No further change in the distribution takes place up to the time of embryo formation (Text-fig. XIV), when they gradually disappear. Starch grains are totally absent in the inner integument, while they accumulate more or less in the basal part of the outer integument, and as the embryo begins to develop they spread over the latter.

As is often the case in many plants, the ovule of Oenothera has an inner integument, whose internal cell-wall facing the nucellus is already fully cuticularized in the mother-cell stage of the gametophyte, as demonstrated with Sudan III. Consequently in the growing ovular tissue, nutritive communication of the nucellus with the raphae is restricted only to the chalazal portion, where the chromatic substance in question makes an early appearance and forms so-called hypostase of Van Tieghem.

Thus, the case would be very easily explained if we assumed the chalazal chromatic substance as a certain nutritive substance which is 
produced in correlation with accumulation of starch grains in the nucellar tissue. But the result of microchemical observations denies any nutritive substance existing there, and, on the contrary, it suggests something like ultimate products.

The writer therefore examined several species of other genera of the Onagraceae with a view to finding a clue to solve the question. Unfortunately, the result of the investigation did not fully answer the expectation, but a close relation existing between the hypostase and starch grains in nucellus was found, which is shown in the following table:

Material.

Oenothera mutans, pycnocurpa,
biennis var. canescens, and odorata

Gaura parviflora

G. Lindheimeri

Circaea quadrisulcata

Ludwigia prostrata

Fussieua repens

Epilobium angustifolium

Godetia sp.

Fuchsia macrostemma

Starch grains in
the nucellus.
many
many
many
many
not so many
few
very few
none
none

Hypostase, i.e. the tissue containing chromatic. substance in the chalazal region.

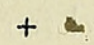
Cuticularization of the walls of the inner integument.

+
+
+
+
-
-
-
-
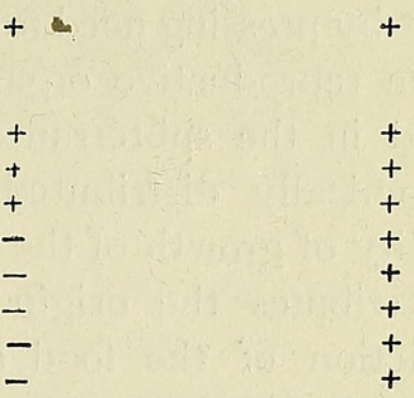

From this table it can be seen clearly that the deposition of numerous starch grains generally occurs when the hypostase is present, and that the chromatic substance interferes with nutritive communication between the nucellus and conducting passage.

Lastly, the question may be discussed from the phylogenetic point of view. As to the affinity among the genera of the Onagraceae, Parmentier's taxonomical and anatomical investigation (54) led to the conclusion that the most primitive type was found in the group to which Ludruigia and Fussieua belong, and that from this group Oenothera was originated and gave rise to other genera. Accepting his conclusion, and reflecting on the result of the present investigation, we can assume that the primitive types scarcely possess hypostase, while in certain derived genera, such as Oenothera and Gaura, the tissue in question is present. It is curious, however, that Godetia, a genus closely related to Oenothera, is entirely destitute of this tissue. In Epilobium, which is a direct derivative of Oenother a, this tissue disappears secondarily, and the same is also the case with Fuchsia, a genus allied both to Oenothera and Ludwigia. On the other hand, it still exists in an isolated genus, Circaea.

It may therefore be concluded that the presence or absence of hypostase and starch grains has no relation with the tetranucleate condition of the embryo sac which is a diagnostic character of the Onagraceae. 


\section{Ecological Consideration of Tetranucleate Embryo. Sac.}

Of the papers dealing with ecological consideration of the tetranucleate embryo sac, those by Magnus (39) and by Kusano (36) seem to be the only ones in which the authors try to explain the origin of the modified embryo sac in detail. According to the former investigator, the feeble reproductive part of the Podostemaceae lifts itself above water at the flowering time, and becomes exposed to the direct sunlight of the Tropics. It is therefore subjected to a xerophytic condition under which, and within only a few days' time, the gametophytic part of the life cycle should be completed. Thus, an abbreviation of certain processes in the gametophyte and some amount of modification in the nucellar tissues are necessarily brought about by pressing need for a rapid growth. Kusano states that in Gastrodia, as the reproductive organs develop at the expense of the food material stored in the subterranean tuber alone, the nutritive substance must be economically distributed to the organs, especially because of the great rapidity of growth of the flower shoot, gametophyte, and the fruit. Thus, he attributes the origin of the abbreviation of the sac to the extreme restriction of the food and time, and concludes that the physiological adaptation in the gametophyte has brought forth morphological adaptation. And, according to him, the embryo is fed for a time with nourishment in the sporophytic tissue, as is the case with the Podostemaceae. However, in the case of Oenothera and other genera of the Onagraceae there is no such pressing ecological condition which can explain the occurrence of the aberrant embryo sac. Nor does any morphological or physiological deviation happen in the ovular tissues, although a curious relation exists between the hypostase and starch grains, which apparently has nothing to do with the tetranucleate gametophyte and development of the embryo. Thus, the writer is led to the conclusion that the tetranucleate condition of the gametophyte of the Onagraceae was caused by mutation, but the subsequent physiological counterbalance was not so markedly disturbed, that it became fixed without any special modification of the surrounding tissues.

\section{Additional Note.}

Among the tetranucleate embryo sacs of the Onagraceae examined by the writer, those of Godetia are the largest, while those of Ludwigia are the smallest. The sac of Gaura comes next to that of Godetia, then follow those of Epilobium, Oenothera, Circaea, and Fussieua, as shown in Text-fig. VIII, I-I2. In Text-fig. VIII, $9 a, 9 b, 9 c$, three successive sections of three developed embryo sacs are shown, which especially are worth mentioning; if they are reconstructed, three mature sacs, which are arranged in an axial row, are obtained. Judging from the remnants of the tapetal cells, the 
uppermost embryo sac is derived from a different mother-cell, while the middle and lowest sacs have a common origin from another one.

\section{SUMMARY.}

I. The embryo sac arises from either micropylar or chalazal one of the tetrad; often both of them simultaneously develop into complete embryo sacs.

2. The embryo sac is tetranucleate, lacking the antipodals and one of the pole nuclei.

3. The pollen-tube enters the synergid through the filiform apparatus and the mixed plasma flows out through the synergid and spreads over the oosphere.

4. The plasma of the pollen grain is impregnated with an immense number of minute fusiform starch grains, which migrate through the pollentube, enter the synergid, and finally become entirely consumed.

5. The male nucleus is enclosed in a distinct plasma sheath, until it reaches the oosphere.

6. One of the male nuclei fuses with the pole nucleus, and gives rise to the endosperm nucleus with diploid number of chromosomes.

7. Synergids and upper two-thirds of the oosphere have a distinct cellulose membrane which sometimes contains also pectic substance. The lower part of the egg-cell acquires a cellulose membrane after fertilization.

8. Self-sterility of some hybrids is due to a feeble growth of the pollen-tube.

9. Besides Oenothera, Ludwigia, Gaura, Godetia, and Circaea also produce tetranucleate embryo sacs, which is a diagnostic character of the Onagraceae. On the other hand, Trapa, which has a normal 8-nucleate embryo sac, would better be separated from the Onagraceae.

I0. The chalazal tissue is nearly occupied by some chromatic substance which appears to be some ultimate substance. Many starch grains accumulate in the young nucellar tissue before the chromatic substance makes an appearance.

II. In other genera examined of the Onagraceae, the nucellar tissue is nearly or entirely devoid of deposition of starch grains, correlated with the absence of the chromatic substance.

I2. Tetranucleate condition in the Onagraceae may have been produced by mutation, but not by adaptation. No relation exists between the tetranucleate condition and the presence of the chromatic substance.

13. The species with 4- or 16-nucleate embryo sacs are mostly herbaceous.

The writer is deeply indebted to Prof. K. Fujii and Prof. K. Shibata for their kind advice and suggestions. Acknowledgements are especially 
due to Prof. G. F. Atkinson, Cornell University, Ithaca, for materials and for his kind help which made the present study possible. The writer also wishes to express his most sincere thanks to Dr. H. Takeda for his kind help in preparing this memoir for publication.

\section{LITERATURE CITED.}

1. Arnoldi, W.: Zur Embryologie einiger Euphorbiaceen. Trav. Musée Bot., Acad. Imp. Sci. St-Pétersbourg, vol. ix, I91 2, pp. I 36-54.

2. Bartlett, H. H.: Systematic Studies on Oenothera. III. Rhodora, vol. xv, 19I3, pp. 8I-5.

3. Beer, R.: On the Development of the Pollen Grain and Anther of some Onagraceae. Beih. Bot. Centralbl., vol. xix, I905, pp. 286-3 I 3 .

4. Blackman, V. H., and Welsford, E. J. : Fertilization in Lilium. Ann. Bot., vol. xxvii, 1913, pp. IIII-I 4 .

5. Brown, W. H.: The Exchange of Material between Nucleus and Cytoplasm in Peperomia Sintensii. Bot. Gaz., vol. xl, 1910, pp. 189-94.

6. Campbell, D. H.: The Embryo Sac of Aglaonema. Scottish Bot. Rev., vol. i, igi2. (Direct consultation has been impossible.)

7. Chamberlain, C. J.: Contribution to the Life-history of Lilium philadelphicum. II. Bot. Gaz., vol. xxiii, 1897, pp. 423-30.

8. Chodat, R., et Bernard, C.: Sur le sac embryonnaire de l'Helosis guayanensis. Journ. Botanique, vol. xiv, 1900, pp. $72-9$.

9. Compton, R. H.: Note on a Case of Doubling of Embryo Sac, Pollen, and Embryo. Ann. Bot., vol. xxvi, 1912, pp. 243-4.

10. : Phenomena and Problem of Self-sterility. New Phytologist, vol. xii, I913, pp. $197-206$.

11. Cook, M. T.: Notes on the Embryology of the Nymphaeaceae. Bot. Gaz., vol. xlviii, 1909, pp. $56-60$.

12. Coulter, J. M.: Relation of Megaspores to Embryo Sacs in Angiosperms. Bot. Gaz., vol. xlv, 1908, pp. $36 \mathrm{I}-6$.

13. Coulter, J. M., and Chamberlain, C. J.: Morphology of Angiosperms. Chicago, I903.

14. DAhlgren, K. V. O. : Ein neuer Typus unter den Angiospermen. Arkiv för Botanik, vol. xiv, I9I5, pp. I-IO.

15. Davis, B. M.: The Reduction Division of Oenothera biennis. Ann. Bot., vol. xxiv, 1910, pp. $63 \mathrm{I}-5 \mathrm{I}$.

16. Digby, L.: The Somatic, Premeiotic, and Meiotic Nuclear Division of Galtonia candicans. Ann. Bot., vol. xxiv, 1910, pp. 727-57.

17. Fischer, G. C. : Seed Development in the Genus Peperomia. Bull. Torrey Bot. Club, vol. xli, I9I 4 , pp. I37-56.

18. Fristendahl, A.: Cytologische und entwicklungsgeschichtliche Studien an Myricaria germanica. Desv. Kungl. Sv., Vetensk. Akad. Handl., vol. xlviii, I9I 2.

19. Gates, R. R. : A Fixing Fluid for Plant Tissues. Science, N. S., vol. xxi, I9Io, p. 234.

19a. : Mutation Factor in Evolution. London, 1915.

20. Geerts, T. H.: Beiträge zur Kenntniss der cytologischen Entwicklung von Oenothera Lamarckiana. Ber. Deut. Bot. Ges., vol. xxv, I 908, pp. 608-I 4.

21. - Beiträge zur Kenntniss der Cytologie und der partiellen Sterilität von Oenothera Lamarckiana. Rec. Trav. Bot. Néerlandais, vol. v, 1909, pp. 93-208.

22. Gibelli, G., et Ferreo, F.: Intorno allo sviluppo dell' ovolo e del seme della Trapa natans, L. Malpighia, vol. v, I 89I, pp. I 56-2 I8.

23. Goldschmidt, R.: Merogonie der Oenotherabastarde und die doppeltreziproken Bastarde von de Vries. Arch. f. Zellforsch., vol. ix, I9I 2, pp. 33I-44. 
24. Guignard, L. : La Double Fécondation dans le Najas Major. Journ. Botanique, vol. xv, I90I, pp. 205-I 3 .

25. Habermann, A. : Fadenapparat in den Synergiden der Angiospermen. Beih. Bot. Centralbl.,

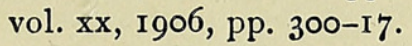

26. Hofmeister, W. : Untersuchungen des Vorgangs bei der Befruchtung der Oenothereen. Bot. Zeitg., vol. xlv, I847.

27. — : Die Entstehung des Embryos der Phanerogamen. 1849.

28. - Neuere Beobachtungen über Embryobildung der Phanerogamen. Jahrb. wiss. Bot., vol. i, $185^{8}$, pp. 28-188.

29. Holmgren, I. : ZurEntwicklungsgeschichte von Butomus umbellatus, L. Svensk Bot. Tidskrift, vol. vii, I9I3, pp. $5^{8-77}$.

30. Huss, H. : Beiträge zur Morphologie und Physiologie der Antipoden. Beih. Bot. Centralbl., vol. $\mathrm{xx}, 1906$, pp. 77-1 74 .

31. Ikeda, T.: Studies in the Physiological Functions of Antipodals and Related Phenomena of Fertilization in Liliaceae. Bull. Col. Agric. Imp. Univ. Tokyo, vol. v, I 902, pp. 4I-72.

32. Johnson, D. S. : Studies on the Development of the Piperaceae. II. Amer. Journ. Bot., vol. i, 19I 4, pp. 323-39, 357-97.

33. Jost, L.: Ueber die Selbststerilität einiger Blüten. Bot. Zeitg., vol. 1xv, 1907, pp. 77-I1 7 .

34. Juel, H. O.: Studien über die Entwicklungsgeschichte von Saxifraga gramulata. Nov. Act. Soc. Sci. Upsal., vol. iv, I907.

35. Körnicke, Max.: Zentrosomen bei Angiospermen? Zugleich ein Beitrag zur Kenntniss der generativen Elemente im Pollenschlauch. Flora, vol. xcvi, I906, pp. 50I-22.

36. Kusano, S.: Experimental Studies on the Embryonal Development in an Angiosperm. Journ. Col. Agric. Imp. Univ. Tokyo, vol. vi, I9I 5, pp. 7-I 20.

37. Lotsy, J. P.: Balanophora globosa, Jungh., eine wenigstens örtlich verwitwete Pflanze. Ann. Jard. Bot. Buitenzorg, vol. xvi, 1899, pp. I74-86.

38. Lutz, A. M. : Triploid Mutants in Oenothera. Biolog. Centralbl., vol. xxxii, I91 2, pp. 385-435.

39. Magnus, W.: Die atypische Embryonalentwicklung der Podostemaceen. Flora, vol. cv, I9I3, pp. $275-336$.

40. Martin, J. H.: Comparative Morphology of some Leguminosae. Bot. Gaz., vol. lviii, I9I4, pp. $154-67$.

41. McAllister, F.: On the Cytology and Embryology of Smilacina racemosa. Trans. Wisconsin Acad. Sci., Arts and Let., vol. xvii, 1913, pp. 599-600.

42. ModilewsKi, J. : Zur Embryobildung von einigen Onagraceen. Ber. Deut. Bot. Ges., vol. xxvii, 1909, pp. 287-92.

43. - Weitere Beiträge zur Embryobildung einiger Euphorbiaceen. Ber. Deut. Bot. Ges., vol. xxviii, I910, pp. 413-18.

44. - Ueber die anomale Embryosackentwicklung der Euphorbia palustris und anderer Euphorbiaceae. Ber. Deut. Bot. Ges., vol. xxix, I9II, pp. 430-6.

45. Molisch, H.: Mikrochemie der Pflanzen. Jena, I9I3.

46. NAWASCHIN, S. : Ueber das selbständige Bewegungsvermögen des Spermakerns bei einigen Angiospermen. Oesterreich. Bot. Zeitschr., vol. xii, I909, pp. I-I I.

47. Bot. Buitenzorg, III ${ }^{e}$ Suppl., vol. ii, I910, pp. 87 I-904.

48. Nawaschin, S., und FinN, V.: Zur Entwicklungsgeschichte der Charazogamen. Fuglans regia und Juglans nigra. Mém. Acad. Imp. Sci. St-Péterșbourg, vol. xxxi, 1913, pp. I-59.

49. NĚmEC, B.: Ueber die Befruchtung bei Gagea. Bull. Internat. Acad. Sci. Bohème, vol. xvii, I9I $2, \mathrm{pp}$. I-I 7 .

50. PACE, L.: Fertilization in Cypripedium. Bot. Gaz., vol. xliv, 1907, pp. 353-72.

51. — : Parnassia and allied Genera. Bot. Gaz., vol. liv, I9I2, pp. 307-29.

51 a. - : Apogamy in Atamosco. Bot. Gaz., vol. lvi, 1913, pp. 371-94.

52. - : Two Species of Gyrostachys. Baylor Univ. Bull., vol. xvii, 19I4, pp. I-16.

53. PALM, B. J. : Ueber die Embryosackentwicklung einiger Kompositeen. Svensk Bot. Tidskrift, vol. viii, 1914, pp. 447-53.

53 a. : Studien über Konstruktionstypen und Entwicklungswege des Embryosackes der Angiospermen. Inaug. Dissert., Stockholm, 1915. 
54. Parmentier, M. P.: Recherches anatomiques et taxonomiques sur les Oenothéracées et les Haloragacées. Ann. Sci. Nat., Bot., vol. viii, 1897, pp. 65-159.

55. Renner, O.: Befruchtung und Embryobildung bei Oenothera Lamarckiana und einigen verwandten Arten. Flora, vol. cvii, I914, pp. I I 5-50.

56. Reed, T.: The Nature of the Double Spirem in Allium Cepa. Ann. Bot., vol. xxviii, I9I4, pp. $27 \mathrm{I}-8 \mathrm{I}$.

57. Schacht, H.: Ueber Pflanzen-Befruchtung. Jahrb. wiss. Bot., vol. i, 1858, pp. 193-232.

58. - Lehrbuch der Anatomie und Physiologie der Gewächse. Berlin, vol. ii, I859.

59. Schwere, S.: Zur Entwicklungsgeschichte der Frucht von Taraxacum officinale, Web., ein Beitrag zur Embryologie der Compositen. Flora, vol. lxxxii, 1896, pp. 32-66.

60. Sharp, L. W.: The Orchid Embryo Sac. Bot. Gaz., vol. liv, I9I 2, pp. 373-85.

61. Shatтuck, C. H. A.: Morphological Study of Ulmus americana. Bot. Gaz., vol. xl, 1905, pp. 209-23.

62. Smith, R. W.: The Tetranucleate Embryo Sac of Clintonia. Bot. Gaz., vol. lii, I9Io, pp. 209-I 7 .

63. Stomps, T. J.: Die Entstehung von Oenothera gigas, de Vries. Ber. Deut. Bot. Ges., vol. xxx, I9I 2, pp. 406-I6.

64. - Mutation bei Oenothera biennis, L. Biolog. Centralbl., vol. xxxii, I9I2, pp. $5^{2} \mathrm{I}-35$.

65. Strasburger, E. : Neue Untersuchungen über die Befruchtung bei den Phanerogamen. Jena, I 884 .

66. $:$ Zu Santahum und Daphne. Ber. Deut. Bot. Ges., vol. iii, 1885, pp. 105-13.

67. : Chromosomenzahlen, Plasmastrukturen, Vererbungsträger und Reduktionsteilung. Jahrb. wiss. Bot., vol. xlv, 1908, pp. 479-570.

68. TÄскноцM, G.: Zur Kenntniss der Embryosackentwicklung von Lopezia coronata, Andr. Svensk Bot. Tidskrift, vol. viii, 19I4, pp. 223-34.

69. : Beobachtungen über die Samenentwicklung einiger Onagraceen. Svensk Bot. Tidskrift, vol. ix, 1915, pp. 294-36r.

70. Tchernoyarow, M.: Les Nouvelles Données dans l'embryologie du Myosurus minimus, L. Mém. Soc. Natural. Kiew, vol. v, 1915, pp. 95-170.

71. Treub, M.: Le Sac Embryonnaire et l'embryon dans les Angiospermes. Ann. Jard. Bot. Buitenzorg, vol. ii, I9I0, pp. I-I 7 .

72. Tunmann, O.: Pflanzenmikrochemie. Berlin, I9I3.

73. Werner, E.: Zur Oekologie atypischer Samenanlagen. Beih. Bot. Centralbl., vol. xxxii, I9I4, Pp. I-I4.

74. Weinzieher, S. : Beiträge zur Entwicklungsgeschichte von Xyris indica, L. Flora, vol. cvi, I9I 4 , pp. 392-432.

75. Welsford, E. J.: The Genesis of the Male Nuclei in Lilium. Ann. Bot., vol. xxviii, I9I4, pp. $26_{5}-70$.

76. Went, F. A., F. C.: Untersuchungen über Podostemaceae. Verhandl. Königl. Akad. Wiss. Amsterdam, vol. ii, 1910.

\section{EXPLANATION OF FIGURES ON PLATE VII.}

Illustrating Mr. Ishikawa's paper on the Embryo Sac and Fertilization in Oenothera.

Figs. I, 6, 8-10, 12, 17, hybrid 'pycnella'; 2-5, 7, Oenothera mutans; I1, 13-16, 18, Oe. nutans fertilized by Oe.pycnocarpa. 1 13-15 $\times 900 ; 1-9,13-16,17,18 \times 1,300$.

Lettering used is as under :

e.c., egg-cell ; e.d., endosperm nucleus; e.n., egg nucleus; fil., filiform apparatus; m.n., male nucleus; $m . s .$, mucilaginous substance; $p$., pollen-tube; $p . f$. , plasma flow from synergid; $p . n$. , pole nucleus; p.s., plasma sheath of male nucleus; rs., residue in pollen-tube; syn., sound synergid; $\operatorname{syn}_{.1}$, attacked synergid ; s.n., uucleus of synergid; $v$., vegetative nucleus. 
Fig. I. Mature pollen grain containing degenerated vegetative nucleus $(v$.) in centre and elliptical generative one $(g$.) lying in peripheral portion. Plasma is impregnated with immense numbers of hyaline fusiform starch grains.

Fig. 2. Pollen-tube in stylar conducting tissue, showing disorganized vegetative nucleus $(v$.), two male nuclei $(m . n$.$) in telophase with plasma sheath, and migrating starch grains.$

Fig. 3. The same, showing a disintegrating vegetative nucleus $(v$.$) .$

Figs. 4-6. Tips of pollen-tubes just lying upon embryo sacs, each of them containing two male nuclei embedded in plasma sheath, no vegetative nuclens.

Fig. 7. The same, typical lenticular male cell is shown.

Fig. 8. Two tubes $\left(p_{0}\right)$ on the sac, one of which made the way between two filiform apparatus ( fil.). Apical end of the tube is closed by mucilaginous substance (m.s.). Synergids (syn.1) are filled with starch grains which originated in the pollen grain.

Fig. 9. $a, b$. Two successive sections of an egg apparatus cut longitudinally; $a$ is to overlap $b$ in the actual state of affairs. Upper synergid $\left(\operatorname{syn}_{._{1}}\right)$ has been attacked by tube $(p \cdot)$, contents commencing to flow out over oosphere (e.c.) through rents $\left(r_{.}, r_{\text {. }}, r_{\text {. }}\right)$.

Fig. Io. Upper part of embryo sac with six endosperm nuclei, two of which (e.n.) are shown in both sides of egg-cell (e.c.).

Fig. II. Egg apparatus with two synergids attacked $\left(s y n_{\cdot 1}\right)$ by tube $(p$.$) .$

Fig. I2. The same, but one synergid attacked.

Fig. I3. Oosphere cut slantingly at the lower end; two male nuclei (m.n.) enclosed in plasma sheaths ( $p . s$.$) lying in plasma flow poured out from synergid.$

Fig. I 4. Two male cells (m.n. and p.s.) in plasma flow (p.f.), through the upper one of which egg nucleus $\left(e_{.} n\right.$.) is visible.

Fig. 15. Two male nuclei (m.n.) are just in contact with female elements (e.n., p.n.).

Fig. 16. Plasma flow upon oosphere. One male cell is shown.

Fig. I 7. Tube end bursting, starch grains flowing into synergid.

Fig. 18. Two branchlets of pollen-tube grasping tip of synergid, filiform apparatus ( $f l$.) turned over, portion of mixed plasma contents flowing over the latter. 


\section{$2 \mathrm{BHL}$ Biodiversity Heritage Library}

Ishikawa, M. 1918. "Studies on the embryo sac and fertilization in Oenothera." Annals of botany 32, 279-318.

https://doi.org/10.1093/oxfordjournals.aob.a089677.

View This Item Online: https://www.biodiversitylibrary.org/item/238284

DOI: https://doi.org/10.1093/oxfordjournals.aob.a089677

Permalink: https://www.biodiversitylibrary.org/partpdf/320220

\section{Holding Institution}

Smithsonian Libraries

\section{Sponsored by}

Biodiversity Heritage Library

\section{Copyright \& Reuse}

Copyright Status: Not in copyright. The BHL knows of no copyright restrictions on this item.

This document was created from content at the Biodiversity Heritage Library, the world's largest open access digital library for biodiversity literature and archives. Visit BHL at https://www.biodiversitylibrary.org. 